\title{
Effects of Row Spacing and Nitrogen Rate on Wheat Grain Yield and Profitability as Influenced by Diseases
}

Jorge David Salgado, Department of Plant Pathology, The Ohio State University, Ohio Agricultural Research and Development Center, Wooster, OH 44691; Laura E. Lindsey, Department of Horticulture and Crop Science, The Ohio State University, Columbus, OH 43210; and Pierce A. Paul, ${ }^{\dagger}$ Department of Plant Pathology, The Ohio State University, Ohio Agricultural Research and Development Center, Wooster, $\mathrm{OH} 44691$

\begin{abstract}
In Ohio, changes in nitrogen $(\mathrm{N})$ fertilizer application rates and row spacing in combination with fungicide applications have been proposed as possible strategies for increasing wheat productivity and profitability. Field experiments were conducted in 2013, 2014, and 2015 to evaluate the benefits of increasing row spacing and $\mathrm{N}$ rates in soft red winter wheat as influenced by diseases. Combinations of narrow $(19 \mathrm{~cm})$ and wide $\left(38 \mathrm{~cm}\right.$ ) row spacings, $\mathrm{N}$ rates ranging from 34 to $180 \mathrm{~kg} \mathrm{ha}^{-1}$, and the fungicide prothioconazole + tebuconazole applied at flag leaf emergence, boot, or early anthesis represented different management programs. Linear mixed model analyses were performed to evaluate the effects of $\mathrm{N}$, row spacing, and fungicide timing on leaf rust, Fusarium head blight (FHB), and deoxynivalenol (DON), and to quantify relationships among leaf rust, N, grain yield (YLD), and test weight (TW). YLD, TW, grain prices and price discounts, as well as input costs were used to estimate net cash income (NCI) for each management program. Wide row wheat

had statistically higher mean FHB and DON, and lower mean yield and test weight than narrow row wheat in 2014 and 2015 but not in 2013 . There were significant positive linear relationships between leaf rust and $\mathrm{N}$ as well as YLD and TW with N. Differences in FHB and DON among $\mathrm{N}$ rates were not statistically significant. Leaf rust severity was consistently lower in treated plots, with efficacy influenced by $\mathrm{N}$ rate and application timing. Programs with narrow row spacing and treated with the fungicide generally resulted in the highest mean YLD and TW across $\mathrm{N}$ rates. Price discounts due to high FDK and DON, and low TW were higher, and consequently, NCIs were lower in 2014 and 2015 than in 2013. The highest NCIs were obtained for programs with the highest YLD and lowest price discounts, consequently programs with wide row spacing, a fungicide treatment, and high $\mathrm{N}$ rates were only economically beneficial when FHB levels were low and grain prices were high.
\end{abstract}

Based on data from the United States Department of Agriculture, National Agricultural Statistics Service, approximately 194,249 ha of SRWW were harvested in Ohio during the 2015 growing season, at an estimated mean yield of $4.51 \mathrm{MT} \mathrm{ha}^{-1}$. At $\$ 169 \mathrm{MT}^{-1}$, the 2014-15 wheat crop was worth approximately \$148 million. During the same season, 1,319,275 ha of corn and 1,918,210 ha of soybean were harvested. At estimated mean yields of 10.29 and 3.36 MT ha ${ }^{-1}$ and grain prices of $\$ 149.5 \mathrm{MT}^{-1}$ and $\$ 325.2 \mathrm{MT}^{-1}$, respectively, the value of the 2015 corn and soybean crops was close to $\$ 2$ billion each. On average, corn, soybean, and wheat were worth approximately $\$ 1,538, \$ 1,093$, and $\$ 762 \mathrm{ha}^{-1}$, respectively. Based on standard production practices in Ohio (Barker et al. 2017), the estimated variable costs of producing a hectare of corn, soybean, and wheat for grain in 2015 were $\$ 952, \$ 529$, and $\$ 498$ (B. Ward, personal communication), respectively. Although wheat is often not the most profitable of the three crops, it is an important component of the rotation in Ohio and other parts of the Midwest as it contributes to the productivity of corn and soybean (E. Nafziger, personal communication) and helps to minimize pest and disease problems and improve soil quality.

Most SRWW cultivars have the potential to yield more than the 2015 average; however, in most years, warm spring and earlysummer conditions usually reduce productivity by shortening the grain fill period (Barker et al. 2017). In addition, wet, humid conditions often favor diseases such as Septoria leaf blotch (Septoria tritici), Stagonospora leaf blotch (Parastagonospora nodorum), tan spot (Pyrenophora tritici-repentis), leaf rust (Puccinia triticina), powdery mildew (Blumeria graminis), and Fusarium head blight (FHB) (Fusarium graminearum), all of which cause yield loss by reducing the photosynthetically active area of the plant (Bhathal et al.

${ }^{\dagger}$ Corresponding author: P. A. Paul; E-mail: paul.661@osu.edu

Accepted for publication 2 July 2017.

() 2017 The American Phytopathological Society
2003; Lackermann et al. 2011; Salgado et al. 2015). Over the last decade, several changes in production practices have been proposed in an effort to increase the productivity and profitability of wheat in Ohio. Some of these include increasing row spacing from 19 to $38 \mathrm{~cm}$; increasing nitrogen rates from the recommended 100-112 $\mathrm{kg} \mathrm{ha}^{-1}$ to $135-180 \mathrm{~kg} \mathrm{ha}^{-1}$ (Paul et al. 2008a); and changing fungicide application programs from a standard full-rate application at Feekes 8 to applications at Feekes 5 or split half-rate applications at both growth stages (Willyerd et al. 2015). In addition, more fungicide applications are being made in the absence of diseases with the hope of increasing grain yield.

There are several reasons why a grower may want to consider planting wheat in wider rows and applying nitrogen $(\mathrm{N})$ at higher rates. For instance, planting wheat at a $38-\mathrm{cm}$ row spacing instead of a $19-\mathrm{cm}$ spacing reduces seed cost, since $50 \%$ less seed is required to plant a hectare at a given seeding rate per meter of row (Richer and Lindsey 2016). In addition, wide-row wheat allows for relay intercropping with soybean (Porter and Khalilian 1995), making it possible for wheat and soybean to be produced in the same field in the same growing season. However, one of the primary reasons why growers are considering planting wheat in wide rows is that it allows for a reduction in equipment inventory (and associated costs), since the same equipment used to plant corn and soybean can be used to plant wide-row wheat. A major disadvantage of wide-row wheat is the fact that fewer plants and spikes may be produced per unit area, which may lead to lower yield (Hussain et al. 2012; Sandler et al. 2015). However, this is very cultivar- and environment-dependent (Hussain et al. 2012). In some cases, more and larger kernels are produced per spike in wide-row wheat, compensating for fewer plants/ spikes and resulting in comparable yields to narrow-row wheat in terms of weight/volume per unit area (Lafond 1994; Lee and Herbek 2012; Porter and Khalilian 1995).

Justifications for increasing nitrogen $(\mathrm{N})$ in wheat include higher grain yield and quality (protein content), but these responses are dependent on several factors, including the $\mathrm{N}$ rate and application timing relative to grain-fill (Denys et al. 2006; Devadas et al. 2014; May et al. 2014). However, $\mathrm{N}$ is also known to affect disease development 
by promoting lush growth that alters the microclimate within the canopy, maintaining leaves green and succulent for a longer time, and changing the $\mathrm{N}$ status of the plant. The specific effect of $\mathrm{N}$ on diseases may vary from one pathosystem to another and depends on the form of $\mathrm{N}$ and when it is applied (Huber and Watson 1974). For instance, $\mathrm{N}$ has been shown to affect the development of rusts, powdery mildew, and Septoria in wheat, with higher severity associated with higher N rates in some cases (Danial and Parlevliet 1995; Devadas et al. 2014; Huber and Watson 1974; Leitch and Jenkins 1995; Shaner and Finney 1977). For rust, this has been attributed, at least in part, to higher humidity within the canopy, changes in the relationship between crop growth and disease progress (Neumann et al. 2004), delayed adult plant resistance in the case of stripe rust (Murray et al. 2005), and increased urediniospore production in the case of leaf rust (Robert et al. 2004). Reciprocally, foliar diseases have also been shown to negatively affect $\mathrm{N}$ uptake and remobilization, and consequently, yield response to N (Bancal et al. 2008; Devadas et al. 2014).

We hypothesize that although increasing row spacing may help to reduce production cost, and that increasing $\mathrm{N}$ may increase grain yield and quality, the economic benefit of these practices will depend on their interaction as well as their effects on other factors such as disease development. For instance, interactions between row spacing and $\mathrm{N}$ rate may compensate for reduced grain yield associated with wide-row wheat, and lower seed cost in wide-row wheat may help to offset increased fertilizer costs associated with higher $\mathrm{N}$ rates, likely resulting in profitable combinations of these factors. However, the effects of $\mathrm{N}$ and row spacing on diseases, the effect of diseases on grain yield and quality, and costs associated with disease management need to be taken into consideration to better assess the benefit of these production practices. Therefore, the objectives of this study were to: 1) determine the effects of row spacing and $\mathrm{N}$ on disease development, grain yield, and test weight; 2) quantify relationships among $\mathrm{N}$ and disease severity, grain yield, and test weight; 3 ) evaluate the efficacy of different fungicide programs as influenced by $\mathrm{N}$ and row spacing; and 4) conduct an economic analysis of management programs consisting of different combinations of row spacing, $\mathrm{N}$ rate, and fungicide application. To accomplish these objectives, field experiments were conducted during the 2013, 2014, and 2015 growing seasons using SRWW cultivar Hopewell. Plots were planted at two row spacings and subjected to different $\mathrm{N}$ and fungicide programs. Linear mixed models were fitted to the data to estimate treatment effects on disease intensity, grain yield, and test weight, and to quantify relationships among these responses and $\mathrm{N}$ as influenced by fungicide treatment and row spacing. Estimates from the fitted models were than used to evaluate the economic benefits of different management programs for a range of grain prices and estimated production costs.

\section{Materials and Methods}

Experimental design and treatment factors. Three field experiments were established at the Snyder Farm of the Ohio Agricultural Research and Development Center, near Wooster, $\mathrm{OH}$, during the 2012-13, 2013-14, and 2014-15 growing seasons. The experimental design was a randomized complete block with a split-split-plot arrangement of $\mathrm{N}$ rate as whole-plot, row spacing as subplot, and fungicide treatment as sub-subplot. Prior to planting, the entire field was moldboard plowed with a Case IH 125 rollover plow (Case IH Agriculture, Racine, WI), disked with a John Deere 111 Pull-type Transport Disk (John Deere, Moline, IL), leveled using a field cultivator Unverferth Perfecta II (Unverferth Manufacturing Co, Inc., Kalida, $\mathrm{OH}$ ), and finished with a culti-mulcher Brillion M124 (Landoll Corporation, Marysville, KS). Urea was applied using a Wilmar Super 150 fertilizer spreader (Willmar Fabrication, LLC., Willmar, $\mathrm{MN})$ at a rate of $49.8 \mathrm{~kg} \mathrm{ha}^{-1}\left(22.4 \mathrm{~kg}\right.$ of $\left.\mathrm{N} \mathrm{ha}^{-1}\right)$. Four pairs of 1.6-m-wide $\times 30$-m-long strips of SRWW cultivar Hopewell (moderatehigh-yielding, moderately resistant to powdery mildew [Blumeria graminis], and susceptible to leaf rust [Puccinia triticina], Stagonospora blotch [Parastagonospora nodorum] and FHB [Fusarium graminearum]) were then planted (between 26 Sept and 6 Oct; Table 1) in each of four blocks at a seeding rate of 82 seeds $\mathrm{m}^{-1}$ of row. One of the strips in each pair was planted with seven rows at a $19-\mathrm{cm}$ spacing, while the other was planted with four rows spaced $38 \mathrm{~cm}$ apart. All plots were planted with a custom-made planter equipped with a GP 20 series row unit, a Singulator-Plus precision seed meter, and high-rate wheat seed discs.

In the spring, between Feekes growth stages 5 and 6 (Table 1), each pair of strips was top-dressed with urea at one of four rates: I - 49.8, II - 149.5 , III - 249.1 , or IV $-348.7 \mathrm{~kg} \mathrm{ha}^{-1}$, for a total of $44.8,89.7,134.5$, and $179.3 \mathrm{~kg}$ of $\mathrm{N} \mathrm{ha}^{-1}$ (summing the fall and spring applications) in 2014 and 2015 . Slightly different rates were used in 2013: $24.9,99.6,174.4$, and $249.1 \mathrm{~kg}$ of urea ha ${ }^{-1}$ (33.6, $67.3,100.9$, and $134.5 \mathrm{~kg}$ of total $\mathrm{N} \mathrm{ha}^{-1}$ ) for $\mathrm{N}$ rates I, II, III, and IV, respectively. All spring applications were made by hand. Alleyways were then cut at $6.1-\mathrm{m}$ intervals along each strip to establish four sub-subplots to which fungicide treatments were applied. These treatments consisted of an untreated check, plus the application of the DMI fungicide Prosaro 421 SC (19\% tebuconazole $+19 \%$

Table 1. Summary of activities, dates, and weather conditions for three experiments conducted in Wooster, $\mathrm{OH}$

\begin{tabular}{|c|c|c|c|}
\hline Activities and conditions & Experiment 1 (2012-13) & Experiment 2 (2013-14) & Experiment 3 (2014-15) \\
\hline \multicolumn{4}{|l|}{ Nitrogen application } \\
\hline Fall - planting & $10 / 4 / 2012$ & $9 / 26 / 2013$ & $10 / 6 / 2014$ \\
\hline Spring - top dressing & $4 / 4 / 2013$ & $5 / 1 / 2014$ & $4 / 17 / 2015$ \\
\hline \multicolumn{4}{|l|}{ Fungicide treatment } \\
\hline Feekes 8 & $5 / 10 / 2013$ & $5 / 14 / 2014$ & $5 / 13 / 2015$ \\
\hline Feekes 10 & $5 / 20 / 2013$ & $5 / 22 / 2014$ & $5 / 18 / 2015$ \\
\hline Feekes 10.5.1 & $5 / 27 / 2013$ & $5 / 29 / 2014$ & $5 / 27 / 2015$ \\
\hline F. graminearum inoculation & $5 / 28 / 2013$ & $5 / 30 / 2014$ & $5 / 28 / 2015$ \\
\hline \multicolumn{4}{|l|}{ Disease assessment } \\
\hline Powdery mildew & $6 / 3 / 2013$ & $\ldots$ & $\ldots$ \\
\hline Stagonospora & $6 / 22 / 2013$ & $\ldots$ & $6 / 18 / 2015$ \\
\hline Leaf rust & $6 / 22 / 2013$ & $6 / 22 / 2014$ & $6 / 18 / 2015$ \\
\hline Fusarium head blight & $6 / 22 / 2013$ & $6 / 22 / 2014$ & $6 / 19 / 2015$ \\
\hline Harvest & $7 / 18 / 2013$ & $7 / 17 / 2014$ & $7 / 7 / 2015$ \\
\hline \multicolumn{4}{|l|}{ Weather summarya } \\
\hline Mean temperature $\left({ }^{\circ} \mathrm{C}\right)$ & 15.56 & 15.82 & 16.22 \\
\hline Mean nighttime RH (\%) & 76.78 & 79.79 & 78.23 \\
\hline \multicolumn{4}{|l|}{ Rainfall } \\
\hline Number of rainy days & $37(7)$ & $42(6)$ & $47(7)$ \\
\hline Total (mm) & $257(35)$ & $316(32)$ & $282(67)$ \\
\hline
\end{tabular}

a Weather conditions were summarized for the months of April, May, and June. For rainfall, values in parentheses represent the number of rainy days and total rainfall during a 15-day window beginning 7 days before and the ending 7 days after anthesis (Feekes 10.5.1). 
prothioconazole, Bayer CropScience, Research Triangle Park, NC) at Feekes 8 (flag leaf emergence), 10 (boot), or 10.5.1 (early anthesis) (Large 1954) at $475 \mathrm{ml} \mathrm{ha}^{-1}$ (100 $\mathrm{g}$ of each active ingredient per hectare). See Table 1 for treatment application dates. All fungicide treatments included the nonionized surfactant Induce (Helena Chem. Company, Collierville, TN) at $0.125 \% \mathrm{v} / \mathrm{v}$, and applications were made with either a tractor mounted or backpack (R\&D Sprayers, Opelousas, LA) sprayer, fitted with XR8001 nozzles (TeeJet Technologies, Dillsburg, PA) and calibrated to deliver 187 liters ha $^{-1}$ at a spray pressure of $207 \mathrm{kPa}$.

Disease intensity, grain yield, and test weight. Since one of the objectives was to evaluate the effects of $\mathrm{N}$ and row spacing on disease development, all plots receiving the Feekes 10.5.1 fungicide treatment were spray inoculated with a spore suspension of $F$. graminearum at anthesis (Feekes 10.5.1; Table 1) as described by Salgado et al. $(2011,2015)$ to enhance FHB development. FHB and naturally occurring leaf diseases were rated on 15 to 20 tillers at six arbitrarily selected locations in each sub-subplot between Feekes 10.5.4 and 11.2 (Table 1). For FHB, severity was estimated as the mean proportion of bleached spikelets per spike, which is commonly referred to as FHB index (Paul et al. 2005). Powdery mildew, leaf rust, and leaf blotch (Septoria and Stagonospora) severity were rated as percent flag leaf area diseased with the aid of diagrammatic rating scales developed using Severity Pro (Nutter and Litwiller 1998). In all cases, incidence was estimated as the mean proportion of diseased leaves or spikes (i.e., number of spikes/leaves with nonzero severity divided by the total number of spikes/leaves rated [110 to 120 per sub-subplot]).

Table 2. Probability values from linear mixed model analyses of the main and interaction effects of nitrogen application rate, row spacing, and fungicide treatment on diseases, the mycotoxin deoxynivalenol, grain yield, and test weight in soft red winter wheat ${ }^{\mathrm{a}}$

\begin{tabular}{rlrccrr}
\hline Year $^{\text {b }}$ & \multicolumn{1}{c}{ Factorc } & Rust & FHB & DON & YLD & TW \\
\hline 2013 & N_RATE & 0.019 & 0.313 & 0.184 & $<0.001$ & 0.004 \\
& SPACE & 0.094 & 0.240 & 0.752 & 0.225 & 0.422 \\
& N_RATE-SPACE & 0.271 & 0.651 & 0.383 & 0.853 & 0.671 \\
& TRT & $<0.001$ & $\ldots$ & $\ldots$ & $<0.001$ & $<0.001$ \\
& N_RATE-TRT & 0.044 & $\ldots$ & $\ldots$ & 0.012 & 0.325 \\
& SPACE-TRT & 0.958 & $\ldots$ & $\ldots$ & 0.362 & 0.056 \\
& N_RATE-SPACE-TRT & 0.735 & $\ldots$ & $\ldots$ & 0.052 & 0.066 \\
N014 & N_RATE & 0.124 & 0.137 & 0.027 & $<0.001$ & 0.016 \\
& SPACE & 0.501 & 0.004 & $<0.001$ & $<0.001$ & $<0.001$ \\
& N_RATE-SPACE & 0.762 & 0.392 & 0.824 & 0.746 & 0.459 \\
& TRT & $<0.001$ & $<0.001$ & $<0.001$ & $<0.001$ & $<0.001$ \\
& N_RATE-TRT & 0.034 & 0.171 & 0.146 & 0.362 & 0.202 \\
& SPACE-TRT & 0.160 & 0.772 & 0.595 & 0.103 & 0.572 \\
N_RATE-SPACE-TRT & 0.818 & 0.888 & 0.876 & 0.675 & 0.991 \\
N_RATE & 0.013 & 0.944 & 0.363 & 0.030 & 0.211 \\
N_RATE & 0.083 & 0.006 & $<0.001$ & $<0.001$ & $<0.001$ \\
SPACE & 0.107 & 0.855 & 0.155 & 0.055 & 0.100 \\
N_RATE-SPACE & $<0.001$ & $<0.001$ & $<0.001$ & $<0.001$ & $<0.001$ \\
& TRT & $<0.001$ & 0.284 & 0.218 & 0.284 & 0.334 \\
N_RATE-TRT & 0.749 & 0.951 & 0.516 & 0.098 & 0.048 \\
SPACE-TRT & 0.268 & 0.134 & 0.946 & 0.815 & 0.805 \\
N_RATE-SPACE-TRT & &
\end{tabular}

a Rust $=$ leaf rust $(\%)$, FHB = Fusarium damaged kernels (FDK; mean proportion of visibly whitish-pinkish kernels) in 2013 and Fusarium head blight index (mean proportion of diseased spikelets per spike) in 2014 and 2015, DON = deoxynivalenol mycotoxin contamination of harvested grain, YLD $=$ grain yield $\left(\mathrm{kg} \mathrm{ha}^{-1}\right)$, and TW $=$ test weight $\left(\mathrm{kg} / \mathrm{cm}^{3}\right)$. All measures of disease were arcsine-square root-transformed before analysis, whereas DON was log-transformed. In 2013, FDK and DON data were only available for inoculated plots.

b Field experiments were conducted in Wooster, OH, during the 2012-13, 2013-14, and 2014-15 wheat growing seasons.

c N_RATE $=$ rate of nitrogen applied per unit area $(33.63,67.25,100.88$, and $134.50 \mathrm{~kg} \mathrm{ha}^{-1}$ in 2013 and 44.83, 89.67, 134.50, or $179.34 \mathrm{~kg} \mathrm{ha}^{-1}$ in 2014 and 2015); SPACE = row spacing (19 or $38 \mathrm{~cm}$ between rows); and TRT = application of the fungicide Prosaro (19\% tebuconazole $+19 \%$ prothioconazole) at a rate of $475 \mathrm{ml} / \mathrm{ha}$ at Feekes 8 (flag leaf emergence), 10 (boot), or 10.5.1 (early anthesis), plus an untreated check.
Plots were harvested using an ALMACO SPC20 (ALMACO, Nevada, IA) research plot combine harvester between the first and third weeks of July (Table 1), when grain moisture was approximately 13 to $15 \%$. Grain yield (bushels per acre), test weight (pounds per bushel), and moisture content were estimated and recorded directly onboard the harvester with an electronic grain gauge (HarvestMaster HM1000 GrainGage, Juniper Systems, Inc., Logan, UT) coupled with a field computer (Allegro MX Field PC, Juniper Systems, Inc.). Grain yield, adjusted to $13.5 \%$ moisture content, was then converted to kilograms per hectare $\left(\mathrm{kg} \mathrm{ha}^{-1}\right)$ and test weight to kilograms per cubic meter $\left(\mathrm{kg} \mathrm{m}^{-3}\right)$ based on a $27-\mathrm{kg}$ bushel weight. Grain samples (one per sub-subplot) were collected from the grain stream during harvest, rated for Fusarium damaged kernels (FDK), and assayed for the mycotoxin deoxynivalenol (DON) as previously described (Salgado et al. 2011).

Data analysis. Linear mixed model analysis of variance. Prior to analysis, leaf rust (RUST), powdery mildew (PM), Stagonospora leaf blotch (STAG), and FHB intensity data were arcsine-square roottransformed to stabilize variance. Each experiment and response was then analyzed separately. The model fitted to the data could be written as:

$$
\begin{aligned}
y_{i j k l}= & \theta+\alpha_{i}+\beta_{j}+\tau_{k}+(\alpha \beta)_{i j}+(\alpha \tau)_{i k}+(\beta \tau)_{j k}+(\alpha \beta \tau)_{i j k} \\
& +b_{l}+\alpha(b)_{i l}+\beta(\alpha b)_{i j l}+e_{i j k l}
\end{aligned}
$$

where $y_{i j k l}$ is the response (dependent variable; arcRUST, arcFHB, arcPM, arcSTAG, yield, and test weight) for the $i$-th nitrogen rate ( $\mathrm{N}$ rate), $j$-th row spacing (SPACE), and $k$-th fungicide treatment (TRT) in the $l$-th block (BLK), $\theta$ is the constant (intercept), $\alpha_{i}$ the effect of the $i$-th N rate, $\beta_{j}$ the effect of the $j$-th SPACE, $\tau_{k}$ the effect of the $k$-th TRT, $(\alpha \beta)_{i j}$ the effect of the $i$-th $N$ rate $\times j$-th SPACE interaction, $(\alpha \tau)_{i k}$ the effect of the $i$-th $\mathrm{N}$ rate $\times k$-th TRT interaction, $(\beta \tau)_{j k}$ the effect of the $j$-th SPACE $\times k$-th TRT interaction, $(\alpha \beta \tau)_{i j k}$ the effect of the $i$-th $\mathrm{N}$ rate $\times j$-th SPACE $\times k$-th TRT interaction, $b_{l}$ the effect of the $l$-th block, $\alpha(b)_{i l}$ the effect of the $i$-th $\mathrm{N}$ rate within the $l$-th block, $\beta(\alpha b)_{i j l}$ the effect of the $j$-th SPACE within the $i$-th N rate within the $l$-th block, and $e_{i j k l}$ the residual. $N$ rate, SPACE, and TRT were considered fixed effects, and block and all interactions involving block were treated as random effects. Models were fitted using the GLIMMIX procedure of SAS (Littell et al. 2006), and fixed and random effects were evaluated with $F$ and standard normal test statistics, respectively. For all significant fixed effects and interactions of fixed effects, contrast and lsmestimate statements in GLIMMIX were used to compare main- and simple-effect means.

Linear mixed model regression analyses. Initial analyses and graphical explorations of the data showed that the interaction effect of $\mathrm{N}$ rate and fungicide treatment on arcRUST was statistically significant (Table 2) and that there was a positive association between $\mathrm{N}$ rate and leaf rust severity. Therefore, mixed model regression analysis was performed to model the relationship between arcRUST and $\mathrm{N}$ rate and to determine the effect of fungicide treatment on leaf rust at different $\mathrm{N}$ rates. Separate models were refitted to the arcRUST data for each experiment using fungicide treatment as fixed effect and $\mathrm{N}$ rate as a continuous covariate. Since the initial analyses (Table 2) also showed that the main and interaction effects of row spacing on arcRUST was generally not statistically significant $(P>$ $0.05)$, SPACE was not included in the models as a fixed effect; however, all random effects terms were maintained as described in equation 1 . The model fitted to the data, with the random effects terms suppressed for simplicity, can be written as:

$$
y_{i j k l m}=\theta+\tau_{k}+\delta X_{m}+\Delta_{k} X_{m}+\ldots+e_{i j k l m}
$$

where $y_{i j k l m}$ is the response (arcRUST), $X_{m}$ is the $m$-th observation of the covariable $\mathrm{N}$ rate, $\delta$ is the (main) effect of the covariable, $\Delta_{k}$ is the interaction effect of the covariable (effect of the fungicide treatment on the relationship between $y$ and $X$ ), and $\theta, \tau_{k}$, and $e_{i j k l m}$ are the same as defined above.

Equation 2 was also used to model relationships between $\mathrm{N}$ rate and grain yield and $\mathrm{N}$ rate and test weight as influenced by row 
spacing $\times$ fungicide treatment combination (SPACE-TRT) through linear mixed model regression analysis. For these analysis, the fungicide treatment term in equation 2 was replaced by a single term representing SPACE-TRT combinations (C1 - narrow row spacing, untreated; $\mathrm{C} 2$ - narrow row spacing, treated with Prosaro at Feekes 8; C3 - narrow row space, treated with Prosaro at Feekes 10; C4 - narrow row spacing, treated with Prosaro at Feekes 10.5.1; C5 - wide row spacing, untreated; C6 - wide row spacing, treated with Prosaro at Feekes 8; C7 - wide row spacing, treated with Prosaro at Feekes 10; and C8 - wide row spacing, treated with Prosaro at Feekes 10.5.1). Following a series of preliminary model-fitting steps during which the significance of $\Delta_{k}$ (the interaction effect) was tested, unequal slope models were fitted to the 2013 and 2015 yield and the 2015 test weight data, whereas common slope models (nonsignificant interaction) were fitted to the 2014 yield and the 2013 and 2014 test weight data.

All models were fitted using the GLIMMIX procedure of SAS, with lsmeans and estimate statements used to estimate and compare regression parameters among fixed effects and least square means at fixed levels of the covariate $\mathrm{N}$.

Economic analysis of fungicide treatment $\times$ row spacing $\times \mathbf{N}$ rate management combinations. For each SPACE-TRT combination, mean grain yield and test weight at low $\left(44.8 \mathrm{~kg} \mathrm{ha}^{-1}\right)$, standard $\left(100.9 \mathrm{~kg} \mathrm{ha}^{-1}\right)$, and high (134.5 $\mathrm{kg} \mathrm{ha}^{-1}$ in 2013 and $180 \mathrm{~kg} \mathrm{ha}^{-1}$ in 2014 and 2015) $\mathrm{N}$ rates were estimated using the parameters in Table 3. Each unique $\mathrm{N}$ rate-SPACE-TRT combination was considered a separate management program for economic analysis, giving a total of 24 programs in each year ( 4 TRT $\times 2$ SPACE $\times 3 \mathrm{~N}$ rate). Gross and net cash incomes at three grain prices (low, medium, and high) were estimated for each management program, and using the program with standard row spacing (narrow) and $\mathrm{N}$ rate $\left(100.9 \mathrm{~kg} \mathrm{ha}^{-1}\right)$ and without a Prosaro application as the reference, economic benefit was estimated as:

$$
E B_{P R O G}=N C I_{P R O G}-N C I_{R E F}
$$

where $E B_{P R O G}=$ economic benefit of using a modified management program $\left(\$ \mathrm{ha}^{-1}\right) ; N C I_{P R O G}=$ net cash income to the producer if the modified management program is used $\left(\$ \mathrm{ha}^{-1}\right)$, and $N C I_{R E F}=$ net cash income to the producer if the standard (the reference program) management program is used. Assuming that the only source of cash income $\left(\$ \mathrm{ha}^{-1}\right)$ is from the sale of wheat grain, $N C I_{R E F}$ depends on the overall production cost associated with standard $\mathrm{N}$ rate and row spacing, without fungicide treatment $\left(\operatorname{Cost}_{R E F}, \$ \mathrm{ha}^{-1}\right)$, as well as grain yield $\left(Y ; \mathrm{MT} \mathrm{ha}^{-1}\right)$, grain price $\left(P, \$ \mathrm{MT}^{-1}\right)$, and total price discount $\left(d c t, \$ \mathrm{MT}^{-1}\right)$ based on test weight (TW), FDK, and DON. Therefore, $N C I_{R E F}$ can be estimated as:

$$
N C I_{R E F}=Y \cdot(P-d c t)-\text { Cost }_{R E F}
$$

Price discount is estimated as:

$$
d c t=t w l+f d k l+d o n l
$$

where $t w l, f d k l$, and $d o n l$ represent individual estimated price discounts due to test weight below and FDK and DON contamination above baseline thresholds established by grain elevators $\left(746.6 \mathrm{~kg} \mathrm{~m}^{-3}\right.$ for test weight, $1 \%$ for FDK, and $2 \mathrm{ppm}$ for DON, Salgado et al. [2011]). Using these thresholds, total price discounts for each management program were estimated based on predicted mean test weight at low, standard, and high $\mathrm{N}$ rates, and mean FDK and DON based on the raw data. If a modified management program is used, net cash income can be estimated as:

$$
N C I_{P R O G}=Y \cdot(P-d c t)-\text { Cost }_{P R O G}
$$

where Cost $_{\text {PROG }}$ represents the total production costs $($ seed $+\mathrm{N}+$ fungicide) associated with the use of a modified management program. In equations 4 and $6, Y \cdot(P-d c t)=$ gross cash income (GCI; income before production costs are subtracted).

For the purpose of these analyses, we assumed an estimated seed cost of $\$ 0.031 / 1,000$ seeds (B. Ward, personal communication), which corresponded to $\$ 116.84 \mathrm{ha}^{-1}$ for narrow-row planting

\begin{tabular}{|c|c|c|c|c|c|c|c|c|c|}
\hline \multirow[b]{2}{*}{ Year } & \multirow[b]{2}{*}{ Spacing $\times$ treatment $^{\mathbf{a}}$} & \multicolumn{4}{|c|}{ Grain yield } & \multicolumn{4}{|c|}{ Test weight } \\
\hline & & Intercept & SE & Slope $^{\mathbf{b}}$ & $\overline{S E}$ & Intercept & SE & Slope $^{b}$ & $\mathbf{S E}$ \\
\hline \multirow[t]{8}{*}{2013} & C1 (Narrow, Check) & $4,173.22$ & 201.96 & $1.70^{\mathrm{ns}}$ & 3.45 & 749.99 & 4.10 & $0.109 * *$ & 0.031 \\
\hline & C2 (Narrow, Feekes 8) & $4,427.40$ & 201.96 & $3.47^{\mathrm{ns}}$ & 3.45 & 758.01 & 4.10 & $0.109 * *$ & 0.031 \\
\hline & C3 (Narrow, Feekes 10) & $4,404.16$ & 201.96 & $4.77 *$ & 3.45 & 762.11 & 4.10 & $0.109 * *$ & 0.031 \\
\hline & C4 (Narrow, Feekes 10.5.1) & $4,259.64$ & 201.96 & $7.16^{* *}$ & 3.45 & 765.34 & 4.10 & $0.109 * *$ & 0.031 \\
\hline & C5 (Wide, Check) & $3,932.22$ & 201.96 & $3.19^{\mathrm{ns}}$ & 2.10 & 749.12 & 4.10 & $0.109 * *$ & 0.031 \\
\hline & C6 (Wide, Feekes 8) & $3,784.25$ & 201.96 & $8.35 * *$ & 2.10 & 754.44 & 4.10 & $0.109 * *$ & 0.031 \\
\hline & C7 (Wide, Feekes 10) & $3,975.47$ & 201.96 & $9.15 * *$ & 2.10 & 764.08 & 4.10 & $0.109 * *$ & 0.031 \\
\hline & C8 (Wide, Feekes 10.5.1) & $4,121.17$ & 201.96 & $6.48 * *$ & 2.08 & 763.45 & 4.10 & $0.109 * *$ & 0.031 \\
\hline \multirow[t]{8}{*}{2014} & C1 (Narrow, Check) & $4,269.59$ & 193.55 & $5.66 * *$ & 1.11 & 768.88 & 6.34 & $0.089 * *$ & 0.023 \\
\hline & C2 (Narrow, Feekes 8) & $4,462.27$ & 193.55 & $5.66 * *$ & 1.11 & 769.77 & 6.34 & $0.089 * *$ & 0.023 \\
\hline & C3 (Narrow, Feekes 10) & $4,636.07$ & 193.55 & $5.66 * *$ & 1.11 & 775.92 & 6.34 & $0.089 * *$ & 0.023 \\
\hline & C4 (Narrow, Feekes 10.5.1) & $4,270.18$ & 193.55 & $5.66 * *$ & 1.11 & 760.43 & 6.34 & $0.089 * *$ & 0.023 \\
\hline & C5 (Wide, Check) & $3,800.00$ & 193.55 & $5.66 * *$ & 1.11 & 757.41 & 6.34 & $0.089 * *$ & 0.023 \\
\hline & C6 (Wide, Feekes 8) & $3,932.47$ & 193.55 & $5.66^{* *}$ & 1.11 & 760.57 & 6.38 & $0.089 * *$ & 0.023 \\
\hline & C7 (Wide, Feekes 10) & $3,949.47$ & 193.55 & $5.66 * *$ & 1.11 & 760.18 & 6.34 & $0.089 * *$ & 0.023 \\
\hline & C8 (Wide, Feekes 10.5.1) & $3,885.53$ & 193.55 & $5.66 * *$ & 1.11 & 748.55 & 6.34 & $0.089 * *$ & 0.023 \\
\hline \multirow[t]{8}{*}{2015} & C1 (Narrow, Check) & $3,917.70$ & 309.19 & $5.68 *$ & 2.17 & 747.86 & 5.61 & $0.035^{\mathrm{ns}}$ & 0.040 \\
\hline & C2 (Narrow, Feekes 8) & $3,674.35$ & 309.19 & $11.02 * *$ & 2.17 & 740.61 & 5.61 & $0.174 * *$ & 0.040 \\
\hline & C3 (Narrow, Feekes 10) & $3,879.08$ & 309.19 & $8.59 * *$ & 2.17 & 748.18 & 5.61 & $0.100 *$ & 0.040 \\
\hline & C4 (Narrow, Feekes 10.5.1) & $3,755.52$ & 309.19 & $6.83 * *$ & 2.17 & 735.14 & 5.61 & $0.053^{\mathrm{ns}}$ & 0.040 \\
\hline & C5 (Wide, Check) & $3,555.03$ & 309.19 & $2.59^{\mathrm{ns}}$ & 2.17 & 734.50 & 5.61 & $0.013^{\mathrm{ns}}$ & 0.040 \\
\hline & C6 (Wide, Feekes 8) & $3,744.45$ & 309.19 & $5.81 *$ & 2.17 & 747.21 & 5.61 & $0.049^{\text {ns }}$ & 0.041 \\
\hline & C7 (Wide, Feekes 10) & $3,848.77$ & 309.19 & $5.19 *$ & 2.17 & 749.30 & 5.61 & $0.025^{\mathrm{ns}}$ & 0.040 \\
\hline & C8 (Wide, Feekes 10.5.1) & $3,585.25$ & 309.19 & $5.62 *$ & 2.17 & 725.49 & 5.61 & $0.050^{\mathrm{ns}}$ & 0.040 \\
\hline
\end{tabular}

Table 3. Estimated intercepts, slopes and corresponding standard errors for relationships between wheat grain yield $\left(\mathrm{kg} \mathrm{ha}{ }^{-1}\right)$ and $\mathrm{N}$ and test weight $\left(\mathrm{kg} / \mathrm{m}^{3}\right)$ and $\mathrm{N}$ (covariate) for different row spacing $\times$ fungicide treatment combinations (categorical fixed effect) from field experiments conducted in Wooster, $\mathrm{OH}$, in 2013,2014 , and 2015

\footnotetext{
${ }^{\mathrm{a}} \mathrm{C} 1-\mathrm{C} 8$ = Production practices consisting of different combinations of row spacing (narrow and wide, 19 and $38 \mathrm{~cm}$ between rows, respectively) and fungicide treatment (Prosaro [19\% tebuconazole $+19 \%$ prothioconazole] at a rate of $475 \mathrm{ml} \mathrm{ha}^{-1}$ at Feekes 8 [flag leaf emergence], 10 [boot], or 10.5 .1 [early anthesis], plus an untreated check). C4 and C8 were inoculated at anthesis with a spore suspension of $F$. graminearum.

${ }^{\mathrm{b}}$ ns $=$ slope not significantly different from zero, $*=$ significant at $\alpha=5 \%$, and $* *=$ significant at $\alpha=1 \%$.
} 
$\left(3.76 \times 10^{6}\right.$ seeds $\left.^{-1}\right)$ and $\$ 66.76 \mathrm{ha}^{-1}$ for wide-row planting $\left(2.15 \times 10^{6}\right.$ seeds ha $\left.{ }^{-1}\right)$. Nitrogen fertilizer cost was estimated at $\$ 0.89 \mathrm{~kg}^{-1}$ of pure $\mathrm{N}$ ( $\$ 375$ for 2,000 lb [907.19 kg] of urea, based on average retail prices for the first quarter of 2016; DTN Fertilizer Index [B. Ward, personal communication]), and fungicide cost at $\$ 61 \mathrm{ha}^{-1}$ (product and application). An additional $\$ 40.43 \mathrm{ha}^{-1}$ was added to the production cost for programs with narrow row spacing as the estimated cost for maintaining a separate planter or drill to plant wheat at a 19-cm row spacing (B. Ward, personal communication). All other production costs not directly related to $\mathrm{N}$ application, row spacing, or fungicide application (such as equipment, land preparation, fuel, planting, and insect and weed control) were assumed to be the same for both the reference (standard) and the modified
A
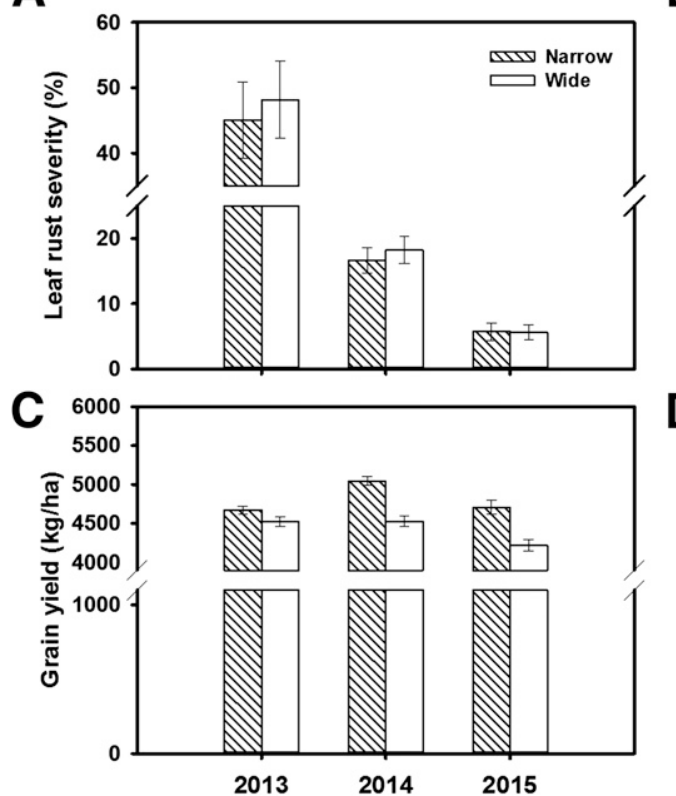

B

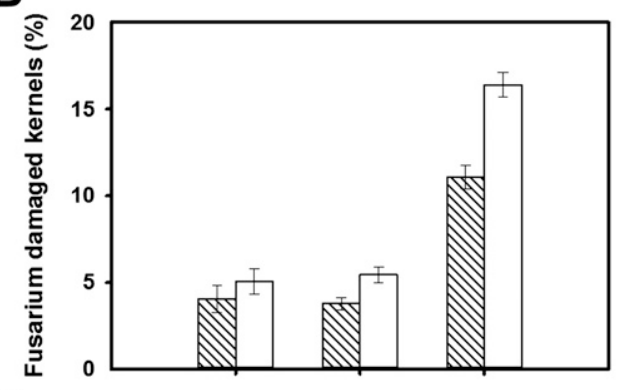

D

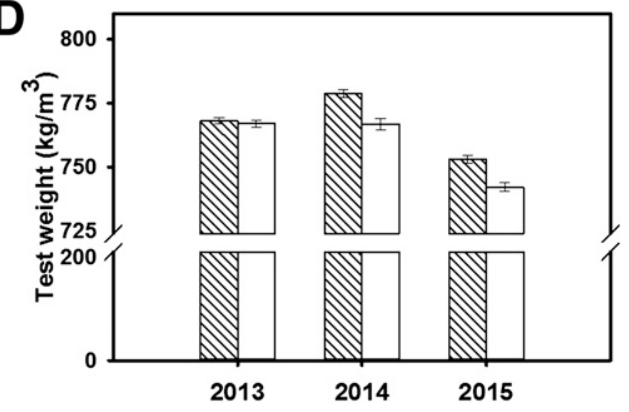

Fig. 1. Arithmetic means of A, leaf rust severity; B, percent Fusarium damaged kernels; C, grain yield; and D, test weight for soft red winter wheat cultivar Hopewell planted in narrow- and wide-row plots (19 and $38 \mathrm{~cm}$ between adjacent rows, respectively) in Wooster, OH, during the 2013, 2014, and 2015 growing seasons. In A, C, and D, each bar represents the mean of 64 observations ( 4 nitrogen application rates $\times 4$ fungicide treatments $\times 4$ blocks). In B, the bar for 2013 represents the mean of 16 observations $(4 \mathrm{~N}$ rates $\times$ 4 blocks) from plots inoculated with a spore suspension of $F$. graminearum, whereas each bar for 2014 and 2015 represents the mean of 64 observation averaged across $\mathrm{N}$ rates, fungicide treatments, and blocks. Error bars are standard errors of the mean.

A

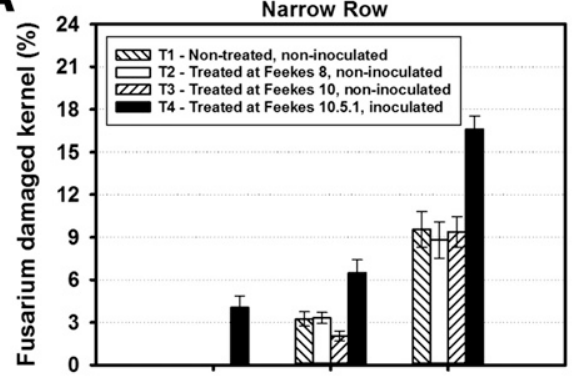

C

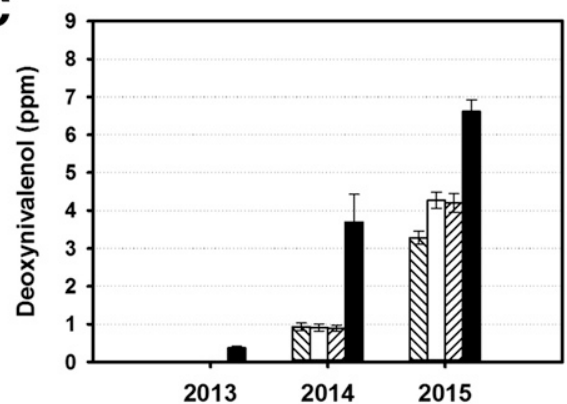

B

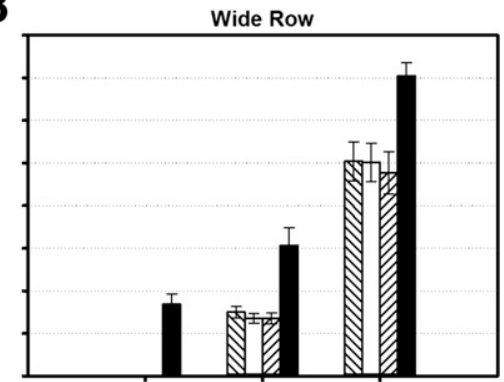

D

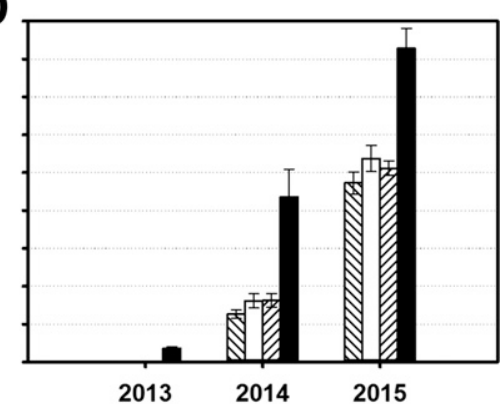

Fig. 2. Arithmetic means of $\mathbf{A}$ and $\mathbf{B}$, Fusarium damaged kernels; and $\mathbf{C}$ and $\mathbf{D}$, deoxynivalenol mycotoxin content of harvested grain for soft red winter wheat cultivar Hopewell planted in narrow- and wide-row plots ( 19 and $38 \mathrm{~cm}$ between adjacent rows, respectively) and subjected to different fungicide $\times$ inoculation treatment combinations in Wooster, OH, during the 2013, 2014, and 2015 growing seasons. T1 = nontreated and noninoculated; T2 = noninoculated and treated with the fungicide Prosaro (19\% tebuconazole $+19 \%$ prothioconazole) at $475 \mathrm{ml} \mathrm{ha}^{-1}$ at Feekes 8 (flag leaf emergence); T3= noninoculated and treated with Prosaro at Feekes 10 (boot); and T4 = inoculated with a spore suspension of F. graminearum and treated with Prosaro at Feekes 10.5.1 (anthesis). Each bar represents the mean of 16 observations (4 nitrogen rates $\times 4$ blocks). Error bars are standard errors of the mean. 
management programs. Therefore, differences between Cost $_{R E F}$ and Cost $_{P R O G}$ are considered due largely to differences in fertilizer application cost, seed cost (which varies with row spacing), cost associated with maintaining a narrow-row planter, and fungicide treatment cost (product plus application). If $N C I_{R E F}$ is less than $N C I_{P R O G}, E B_{P R O G}$ is greater than 0 and there will be a net economic benefit for using a modified management program over the standard program; otherwise, the standard program will be more economically beneficial.

\section{Results}

Row spacing effect on diseases, grain yield, and test weight. Leaf rust and FHB were the most prevalent and severe diseases during the three years of this study, and as such, will be the primary focus of this publication. Averaged across $\mathrm{N}$ rates, row spacings, and blocks, mean flag leaf rust severity in the untreated check was $98 \%$ in 2013 , $32 \% 2014$, and $20 \%$ in 2015 . Mean powdery mildew severity in the untreated check was $2 \%$ on the flag leaf in 2013 and $<1 \%$ in 2014 and 2015. Higher levels of leaf blotch (Stagonospora and Septoria) were observed on the flag leaf in 2015 than in 2014 and 2013, with a mean flag leaf severity of $27 \%$ in 2015 compared with $<1 \%$ in the other two years. FHB developed naturally (without artificial inoculation) in 2014 and 2015, but not in 2013. Mean FDK and DON grain content, averaged across untreated, noninoculated plots, were $12 \%$ and 4 ppm, respectively, in 2015, and $4 \%$ and $1 \mathrm{ppm}$, respectively,
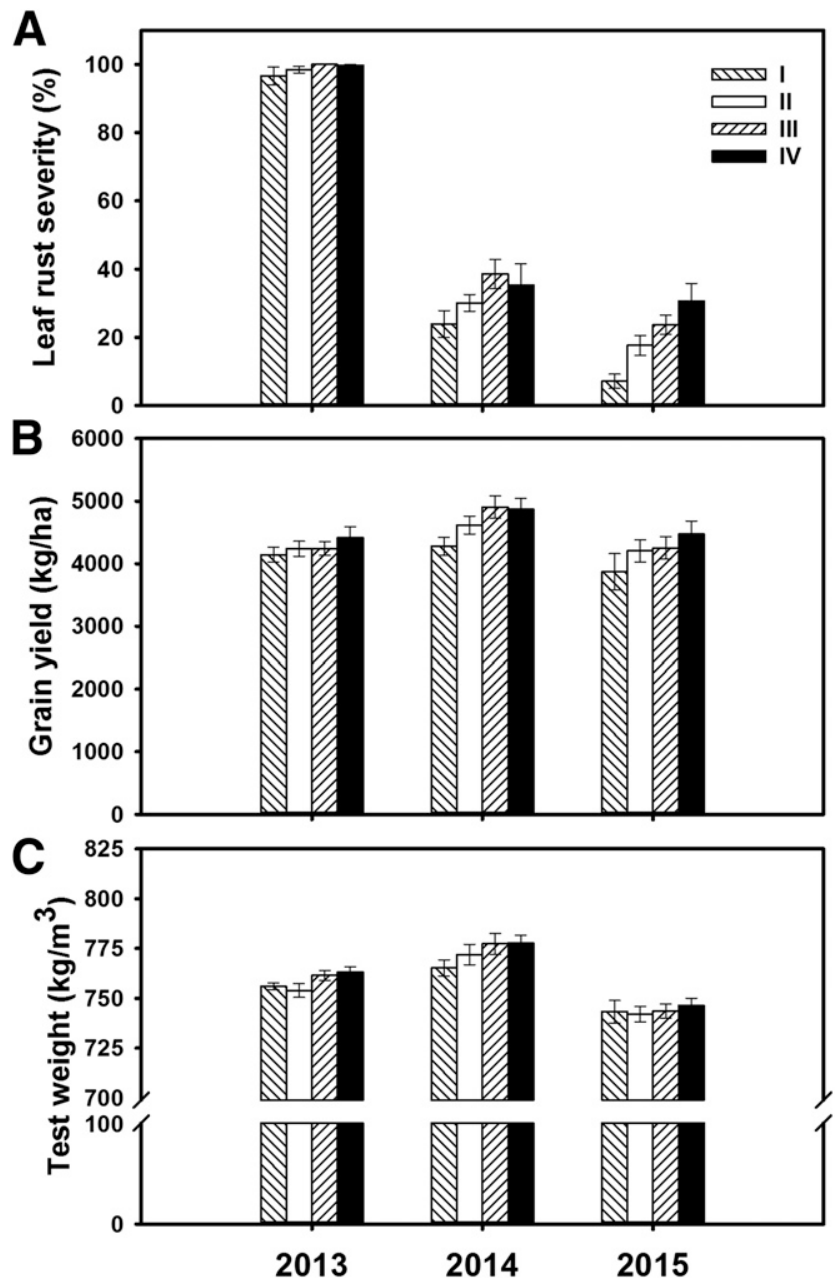

Fig. 3. Arithmetic means of A, leaf rust severity; $\mathbf{B}$, grain yield; and $\mathbf{C}$, test weight for soft red winter wheat cultivar Hopewell treated with four different rates of nitrogen in Wooster, $\mathrm{OH}$, during the 2013, 2014, and 2015 growing seasons. $\mathrm{N}$ rates are $\mathrm{I}=$ $33.6 \mathrm{~kg} \mathrm{ha}^{-1}$ in 2013 and $44.8 \mathrm{~kg} \mathrm{ha}^{-1}$ in 2014 and 2015; $\|=67.3 \mathrm{~kg} \mathrm{ha}^{-1}$ in 2013 and $89.7 \mathrm{~kg} \mathrm{ha}^{-1}$ in 2014 and 2015; III = $100.9 \mathrm{~kg} \mathrm{ha}^{-1}$ in 2013 and 134.5 $\mathrm{kg} \mathrm{ha}^{-1}$ in 2014 and 2015; and IV $=134.5 \mathrm{~kg} \mathrm{ha}^{-1}$ in 2013 and $179.3 \mathrm{~kg} \mathrm{ha}^{-1}$ in 2014 and 2015. Each bar represents the mean of 8 observations (2 row spacings $\times 4$ blocks) from non-fungicide-treated plots. Error bars are standard errors of the mean. in 2014. Mean FDK and DON in grain samples from $F$. graminearum inoculated plots (T4) were 5\% and $0.4 \mathrm{ppm}$, respectively, in $2013,8 \%$ and 4 ppm in 2014, and 19\% and 8 ppm in 2015 .

Row spacing affected disease development as well as grain yield and quality (in terms of FDK, DON, and test weight), but the magnitude and significance of this effect depended on the response and varied among years (Table 2). Averaged across $\mathrm{N}$ rates and fungicide treatments, leaf rust severity was generally higher in wide-row compared with narrow-row plots (Fig. 1). However, differences in mean severity between the two row spacings were not statistically significant $(P>0.05$, Table 2$)$. Compared with leaf rust, the effect of row

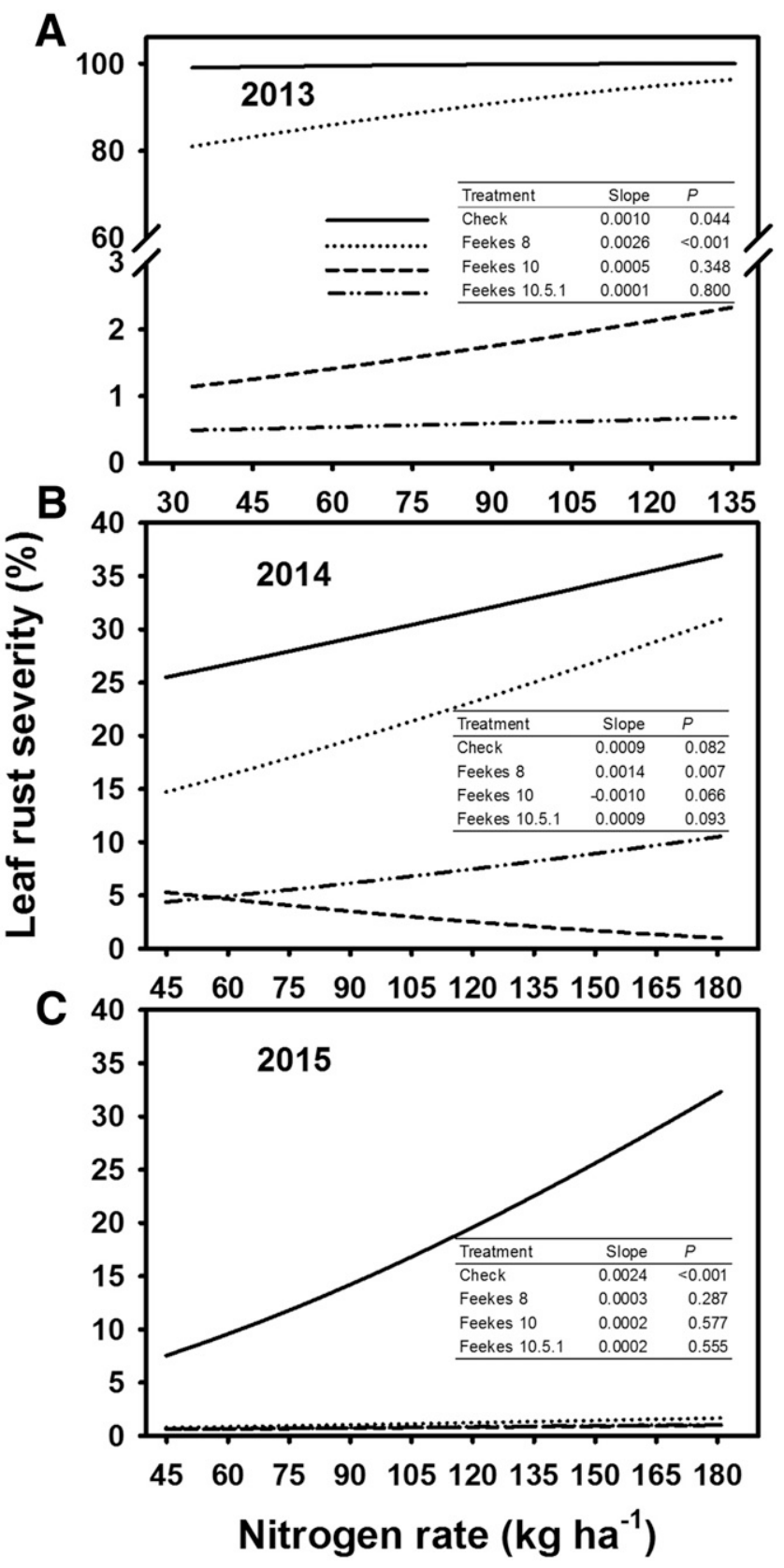

Fig. 4. Relationships between leaf rust severity and nitrogen rate for different fungicide treatments for soft red winter wheat cultivar Hopewell in Wooster, OH, during the 2013, 2014 , and 2015 growing seasons. Lines are back-transformed predicted leaf rust severity from linear mixed model regression analyses. Solid lines represent untreated checks; dotted lines are Prosaro (19\% tebuconazole $+19 \%$ prothioconazole) fungicide treatments applied at $475 \mathrm{ml} \mathrm{ha}^{-1}$ at Feekes 8 (flag leaf emergence); broken lines represent Prosaro applied at Feekes 10 (boot); and broken lines with dots represent Prosaro applied at Feekes 10.5.1 (anthesis). Inserts show estimated slopes on the arcsine-square root-transformed scale and their corresponding levels of significance ( $P$-value). 
spacing on FHB intensity was much more consistent across growing seasons. For all measures of FHB, means were lower in narrow-row plots than in wide-row plots (Figs. 1B and 2; only means for FDK and DON are shown), with the differences in mean index (IND, quantified in 2014 and 2015), FDK, and DON (all on the transformed scale) between the two row spacings being statistically significant in 2014 and 2015 (Table 2). The magnitude of the difference in mean FHB intensity and DON contamination between $19-$ and $38-\mathrm{cm}$ row spacings was similar across fungicide treatments (Fig. 2; nonsignificant treatment $\times$ spacing interaction [Table 2]), ranging from 1 to $2.7 \%$ for FDK and 0.3 to $0.7 \mathrm{ppm}$ for DON in 2014, and from 4.9 to $5.5 \%$ for FDK and 0.9 to $1.6 \mathrm{ppm}$ for DON in 2015. For both row spacings, $F$. graminearum-inoculated plots had significantly higher mean FDK ( 3 to 5\% in 2014 and 6 to $7 \%$ in 2015) and DON (between 2 and 4 ppm in both years) than noninoculated plots, in spite of the anthesis fungicide treatment (Fig. 2).

In all three experiments, mean grain yield and test weight were lower in wide-row than in narrow-row plots (Fig. 1). Averaged across $\mathrm{N}$ rates and fungicide treatments, mean grain yield was 152,518 , and
$484 \mathrm{~kg} \mathrm{ha}^{-1}$ lower in wide rows than in narrow rows in 2013, 2014, and 2015, respectively (Fig. 1). The corresponding differences in mean test weight between the two spacings were 1,12 , and $10 \mathrm{~kg} \mathrm{~m}^{-3}$ in 2013 , 2014 , and 2015, respectively. For both responses, the main effect of row spacing was statistically significant in the second and third years of the study, but not in the first $(P<0.05$, Table 2$)$. There was some evidence of a fungicide treatment effect on yield and test weight responses to row spacing in 2013 and 2015, but not in 2014 (Table 2; $P<0.07$ for three-way interactions in 2013 and $P<0.10$ for the spacing $\times$ treatment [SPACE-TRT] interaction in 2015).

Influence of $\mathrm{N}$ on disease development and the efficacy of Prosaro against leaf rust. Data from untreated plots (averaged across row spacing and blocks) showed that leaf rust severity increased with increasing $\mathrm{N}$ rates in all three years, with mean severity ranging from 96.6 to $100 \%$ in $2013,23.9$ to $38.7 \%$ in 2014 , and 7.1 to $30.7 \%$ in 2015 (Fig. 3). However, similar levels of FHB intensity were observed across $\mathrm{N}$ rates in any given year. Differences in mean IND, FDK, and DON among $\mathrm{N}$ rates were not statistically significant (Table 2). Based on results from LMM analysis of arcsine-square root-transformed leaf

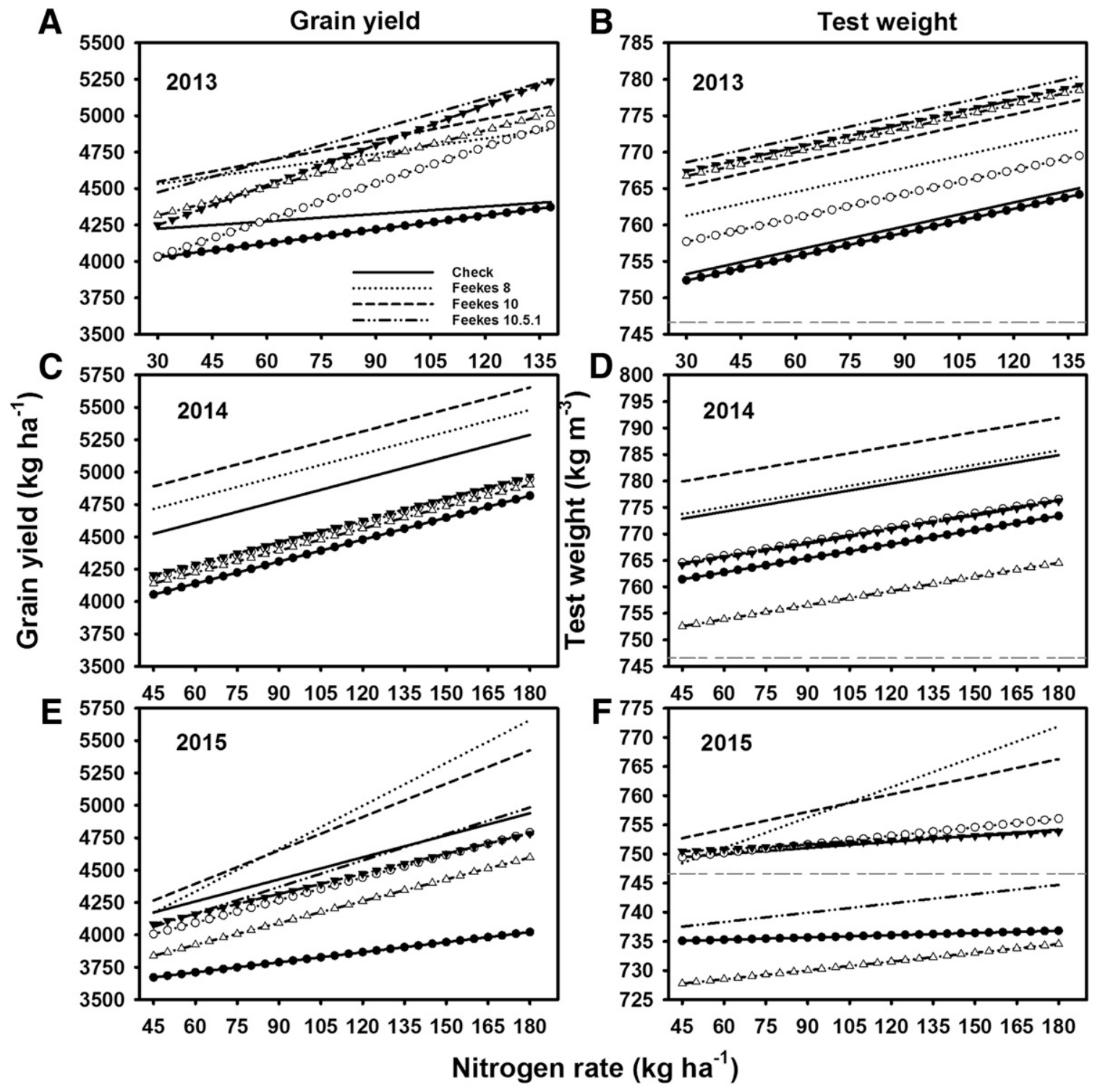

Fig. 5. Relationships between grain yield and $\mathrm{N}$ rate $(\mathbf{A}, \mathbf{C}$, and $\mathbf{E})$ and test weight and $\mathrm{N}$ rate $(\mathbf{B}, \mathbf{D}$, and $\mathbf{F})$ for different fungicide treatment $\times$ row spacing combinations for soft red winter wheat cultivar Hopewell in Wooster, $\mathrm{OH}$, during the 2013, 2014, and 2015 growing seasons. Lines are predicted grain yield and test weight from linear mixed model regression analyses. Solid lines represent untreated checks; dotted lines are Prosaro (19\% tebuconazole $+19 \%$ prothioconazole) fungicide treatments applied at $475 \mathrm{ml} \mathrm{ha}{ }^{-1}$ at Feekes 8 (flag leaf emergence); broken lines represent Prosaro applied at Feekes 10 (boot); and broken lines with dots represent Prosaro applied at Feekes 10.5 .1 (anthesis). Symbols are for wide-row (38 $\mathrm{cm}$ between rows) and no symbols for narrow-row (19 $\mathrm{cm}$ between rows) spacings, with closed circle = wide-row untreated, open circle = wide-row treated at flag leaf emergence, closed triangle $=$ wide-row treated at boot, and open triangle $=$ wide-row treated at anthesis and inoculated with a spore suspension of $F$. graminearum. Horizontal reference lines in B, D, and $\mathbf{F}$ show the test weight threshold $\left(746.6 \mathrm{~kg} / \mathrm{cm}^{3}\right)$ below which discounts for low test weight are applied. 
rust severity (arcRust), both the main effect of fungicide treatment (TRT) and its interaction with $\mathrm{N}$ rate were statistically significant in all three years $(P<0.05$, Table 2$)$, indicating that the effect of fungicide treatment on leaf rust varied with $\mathrm{N}$ rate and vice versa. Furthermore, results from mixed model regression analyses showed that the magnitude and significance of the regression slope (the rate of arcRUST increase per unit increase in $\mathrm{N}$ rate) for relationships between arcRUST and $\mathrm{N}$ rate varied among fungicide treatments and growing seasons (inserts in Fig. 4A-C).

Using predicted back-transformed rust severity in the untreated check as the reference, percent control was estimated as $\hat{C}=\left[\left(\hat{X}_{C}-\hat{X}_{T}\right) / \hat{X}_{C}\right] \times 100$ for each fungicide treatment across tested $\mathrm{N}$ rates; $\hat{X}_{C}=$ height of the regression line (predicted severity) for the untreated check and $\hat{X}_{T}=$ height of the regression line for a fungicide treatment (Fig. 4A-C). Using $\hat{C}$ as a measure of fungicide efficacy, treatments applied at boot and early-anthesis (Feekes 10 and 10.5.1, respectively) consistently reduced leaf rust severity relative to the check in all experiments, at all tested $\mathrm{N}$ rates (Fig. 4A-C), with between 92 and $99 \%$ control in 2013 and 2015 and between 72 and $97 \%$ control in 2014. The Feekes 8 (flag leaf) treatment also reduced rust severity relative to the check, with comparable efficacy to those observed for the Feekes 10 and 10.5.1 treatments in 2015, but much lower efficacy in 2013 and 2014. Rust severity was reduced by 4 to $17 \%$ in 2013 and 16 to $42 \%$ in 2014 with the flag leaf treatment, with the highest $\hat{C}$ values at the lowest tested $\mathrm{N}$ rates and the lowest at the highest $\mathrm{N}$ rates (Fig. 4A and $\mathrm{B}$ ).

Influence of fungicide treatment and row spacing on relationships between yield and $\mathrm{N}$ and test weight and nitrogen. Models were fitted to the data to quantify relationships between yield and $\mathrm{N}$ and between test weight and $\mathrm{N}$ as influenced by fungicide treatment $x$ row spacing combinations. Results from these analyses showed that the intercept (height of the regression line) and/or the slope (rate of yield increase per $\mathrm{kg}$ increase in $\mathrm{N}$ ) varied with fungicide treatment $\times$ row spacing combination (Table 3 and Fig. 5A, C, and E). In 2013 and 2015, for most of the combinations that included a fungicide application, except for the Feekes 8 treatment in narrow-row plots in 2013 (C2), there was a significant positive relationship between $\mathrm{N}$ rate and yield $(P<0.05$, Table 3$)$, with a 4.77 to $11.02 \mathrm{~kg} \mathrm{ha}^{-1}$ increase in yield per kg increase in N. Slopes were also positive and within a similar range $\left(5.66 \mathrm{~kg} \mathrm{ha}^{-1}\right)$ in 2014 , but did not vary among SPACE-TRT combinations (Table 3, Fig. 5C; nonsignificant SPACE-TRT $\times$ covariate interaction).

Table 4 shows estimated differences in mean grain yield between pairs of SPACE-TRT combinations. In 2013, fungicide-treated, narrowrow plots $(\mathrm{C} 2, \mathrm{C} 3$, and $\mathrm{C} 4)$ had significantly higher mean grain yield than the reference SPACE-TRT combination $(\mathrm{C} 1$ - narrow row, untreated) at low, standard, and high $\mathrm{N}$ rates. Differences in mean yield between fungicide-treated, wide-row plots $(\mathrm{C} 6, \mathrm{C} 7$, and $\mathrm{C} 8)$ and $\mathrm{C} 1$ were not statistically significant $(P>0.05)$ at the low $\mathrm{N}$ rate, but both the magnitude and significance of the differences between these programs and $\mathrm{C} 1$ increased as $\mathrm{N}$ rate increased (Table 4, Fig. 5A). For both row spacings, the Feekes 10 (C3 and C7) and Feekes 10.5.1 (C4 and C8) treatments resulted in the highest mean yield increases relative to $\mathrm{C} 1$ at the standard and high $\mathrm{N}$ rates.

In 2014 and 2015, years with the highest levels of FHB, trends were somewhat different from those observed in 2013. Wide-row plots ( $\mathrm{C} 5, \mathrm{C} 6, \mathrm{C} 7$, and $\mathrm{C} 8$ ), regardless of fungicide treatment and $\mathrm{N}$ rate, had lower mean yields than $\mathrm{C} 1$. Differences between $\mathrm{C} 1$ (untreated narrow-row wheat) and C5 (untreated wide-row wheat) at the three $\mathrm{N}$ rates were statistically significant in both years $(P<0.05$, Table 4$)$. In 2014, only applications made at flag leaf emergence and boot (Feekes 8 and 10) in narrow-row plots (C2 and C3) had significantly higher mean yield than $\mathrm{C} 1$ (Table 4), with the magnitude of the difference being the same across all tested $\mathrm{N}$ rates (Fig. 5C). In 2015, C2 and C3 were also the only combinations with significantly higher mean yield than $\mathrm{C} 1$ at standard and high $\mathrm{N}$ rates, with the magnitude of the differences being greatest at the high $\mathrm{N}$ rate (Table 4; Fig. 5E).

Like grain yield, test weight also increased with increasing $\mathrm{N}$ rate for most row spacing $\times$ fungicide treatment (SPACE-TRT) combinations, particularly in 2013 and 2014, but unlike yield, the rates of test weight increase per unit increase in $\mathrm{N}$ (slopes) were more consistent

Table 4. Estimated difference in mean wheat grain yield between pairs of fungicide treatment $\times$ row spacing combinations at fixed rates of nitrogen and corresponding standard errors (se) and levels of significance ( $P$ value) from field experiments conducted in Wooster, OH, in 2013, 2014, and 2015

\begin{tabular}{|c|c|c|c|c|c|c|c|c|c|c|}
\hline \multirow[b]{2}{*}{ N rate ${ }^{\mathbf{a}}$} & \multirow[b]{2}{*}{ Contrast $^{\mathbf{b}}$} & \multicolumn{3}{|c|}{2013} & \multicolumn{3}{|c|}{2014} & \multicolumn{3}{|c|}{2015} \\
\hline & & Diff $^{\mathrm{c}}$ & SE & $P$ & Diff $^{\mathrm{c}}$ & SE & $P$ & Diff $^{\mathrm{c}}$ & SE & $P$ \\
\hline \multirow[t]{7}{*}{ Low } & $\mathrm{C} 1$ versus $\mathrm{C} 2$ & 333.47 & 114.26 & 0.005 & 192.68 & 86.42 & 0.028 & -2.38 & 189.84 & 0.990 \\
\hline & $\mathrm{C} 1$ versus $\mathrm{C} 3$ & 368.74 & 114.26 & 0.002 & 366.48 & 86.42 & $<0.001$ & 92.46 & 189.84 & 0.628 \\
\hline & $\mathrm{C} 1$ versus $\mathrm{C} 4$ & 331.20 & 114.26 & 0.005 & 0.59 & 86.42 & 0.995 & -108.33 & 189.84 & 0.570 \\
\hline & $\mathrm{C} 1$ versus $\mathrm{C} 5$ & -173.99 & 187.22 & 0.361 & -469.59 & 113.84 & $<0.001$ & -499.88 & 183.38 & 0.008 \\
\hline & $\mathrm{C} 1$ versus $\mathrm{C} 6$ & -90.92 & 187.22 & 0.631 & -337.12 & 113.84 & 0.005 & -165.64 & 183.38 & 0.369 \\
\hline & $\mathrm{C} 1$ versus $\mathrm{C} 7$ & 136.07 & 187.22 & 0.474 & -320.12 & 113.84 & 0.007 & -89.33 & 183.38 & 0.627 \\
\hline & $\mathrm{C} 1$ versus $\mathrm{C} 8$ & 162.36 & 187.22 & 0.394 & -384.06 & 113.84 & 0.002 & -334.10 & 183.38 & 0.072 \\
\hline \multirow[t]{7}{*}{ Standard } & $\mathrm{C} 1$ versus $\mathrm{C} 2$ & 432.60 & 86.60 & $<0.001$ & 192.68 & 86.42 & 0.028 & 295.96 & 116.24 & 0.013 \\
\hline & $\mathrm{C} 1$ versus $\mathrm{C} 3$ & 541.02 & 86.60 & $<0.001$ & 366.48 & 86.42 & $<0.001$ & 255.17 & 116.24 & 0.031 \\
\hline & $\mathrm{C} 1$ versus $\mathrm{C} 4$ & 637.23 & 86.60 & $<0.001$ & 0.59 & 86.42 & 0.995 & -45.53 & 116.24 & 0.696 \\
\hline & $\mathrm{C} 1$ versus $\mathrm{C} 5$ & -90.22 & 141.90 & 0.530 & -469.59 & 113.84 & $<0.001$ & -673.38 & 112.29 & $<0.001$ \\
\hline & $\mathrm{C} 1$ versus C6 & 281.71 & 141.90 & 0.058 & -337.12 & 113.84 & 0.005 & -158.77 & 112.29 & 0.161 \\
\hline & $\mathrm{C} 1$ versus $\mathrm{C} 7$ & 553.43 & 141.90 & 0.001 & -320.12 & 113.84 & 0.007 & -117.59 & 112.29 & 0.298 \\
\hline & $\mathrm{C} 1$ versus $\mathrm{C} 8$ & 430.42 & 141.90 & 0.005 & -384.06 & 113.84 & 0.002 & -337.63 & 112.29 & 0.003 \\
\hline \multirow[t]{7}{*}{ High } & $\mathrm{C} 1$ versus $\mathrm{C} 2$ & 492.07 & 132.27 & $<0.001$ & 192.68 & 86.42 & 0.028 & 713.59 & 189.84 & $<0.001$ \\
\hline & $\mathrm{C} 1$ versus $\mathrm{C} 3$ & 644.35 & 132.27 & $<0.001$ & 366.48 & 86.42 & $<0.001$ & 482.94 & 189.84 & 0.013 \\
\hline & $\mathrm{C} 1$ versus $\mathrm{C} 4$ & 820.80 & 132.27 & $<0.001$ & 0.59 & 86.42 & 0.995 & 42.39 & 189.84 & 0.824 \\
\hline & $\mathrm{C} 1$ versus $\mathrm{C} 5$ & -39.98 & 216.74 & 0.855 & -469.59 & 113.84 & $<0.001$ & -916.26 & 183.38 & $<0.001$ \\
\hline & $\mathrm{C} 1$ versus $\mathrm{C} 6$ & 505.23 & 216.74 & 0.028 & -337.12 & 113.84 & 0.005 & -149.15 & 183.38 & 0.418 \\
\hline & $\mathrm{C} 1$ versus $\mathrm{C} 7$ & 803.78 & 216.74 & 0.001 & -320.12 & 113.84 & 0.007 & -157.16 & 183.38 & 0.394 \\
\hline & $\mathrm{C} 1$ versus $\mathrm{C} 8$ & 591.20 & 216.74 & 0.011 & -384.06 & 113.84 & 0.002 & -342.57 & 183.38 & 0.065 \\
\hline
\end{tabular}

a Nitrogen rate: low $=44.83 \mathrm{~kg} \mathrm{ha}^{-1}$, standard $=100.88 \mathrm{~kg} \mathrm{ha}^{-1}$, and high $=134.50 \mathrm{~kg} \mathrm{ha}^{-1}$ in 2013 and $179.34 \mathrm{~kg} \mathrm{ha}^{-1}$ in 2014 and 2015.

${ }^{b}$ Fungicide $\times$ row spacing treatment combinations: $\mathrm{C} 1=$ narrow row spacing and untreated check; $\mathrm{C} 2=$ narrow row and application of the fungicide Prosaro $(19 \%$ tebuconazole $+19 \%$ prothioconazole) at a rate of $475 \mathrm{ml} \mathrm{ha}^{-1}$ at Feekes 8 (flag leaf emergence); $\mathrm{C} 3=$ narrow row and Prosaro at Feekes 10 (boot); $\mathrm{C} 4=$ narrow row and Prosaro at Feekes 10.5.1 (anthesis); C5 = wide row and untreated check; $\mathrm{C} 6=$ wide row and Prosaro at Feekes 8; $\mathrm{C} 7=$ wide row and Prosaro at Feekes 10; and C8 $=$ wide row and Prosaro at Feekes 10.5.1. C4 and C8 were inoculated at anthesis with a spore suspension of $F$. graminearum.

${ }^{\mathrm{c}}$ Differences and corresponding statistics are based on predicted responses from linear mixed model regression analysis of relationships between grain yield and $\mathrm{N}$ (the continuous covariate). 
among SPACE-TRT combinations (Table 3, Fig. 5B, D, and F). In 2015, slopes were positive but not significantly different from zero for all but C2 and C3, Feekes 8 and Feekes 10 applications of Prosaro in narrowrow plots (Table 3, Fig. 5F). In 2013, regardless of row spacing and $\mathrm{N}$ rate, untreated plots ( $\mathrm{C} 1$ and $\mathrm{C} 5)$ had the lowest test weights, while plots treated at Feekes $10(\mathrm{C} 3$ and $\mathrm{C} 7)$ or 10.5.1 (C4 and C8) had the highest (Fig. 5B). In 2014 and 2015, untreated and inoculated-treated wide-row plots (C5 and C8) had the lowest mean test weight at all $\mathrm{N}$ rates, whereas narrow-row plots treated at Feekes 8 or Feekes 10 had the highest (Fig. $5 \mathrm{D}$ and $\mathrm{F}$ ). The magnitude of the differences between pairs of SPACETRT combinations varied with N rate in 2015 (Fig. 5F) but not in 2014 (Fig. 5D).

Economic analysis of management programs. Price discounts. Total price discounts $(d c t)$ were estimated at low $\left(44.8 \mathrm{~kg} \mathrm{~N} \mathrm{ha}^{-1}\right)$, standard $\left(100.88 \mathrm{~kg} \mathrm{~N} \mathrm{ha}^{-1}\right)$, and high $\left(134.5 \mathrm{~kg} \mathrm{~N} \mathrm{ha}^{-1}\right.$ in 2013 and $179.3 \mathrm{~kg} \mathrm{~N} \mathrm{ha}^{-1}$ in 2014 and 2015) $\mathrm{N}$ rates as the sum of discounts due to test weight $(t w l)$ below, and FDK $(f d k l)$ and DON (donl) above predetermined thresholds (Salgado et al. 2011, 2014). In 2013 and 2014, all programs had test weights above the threshold of $746.6 \mathrm{~kg} \mathrm{~m}^{-3}$ (752.5 to $791.9 \mathrm{~kg} \mathrm{~m}^{-3}$, Fig. 5B and D) and as such did not receive price discounts for low test weight (Fig. 6A and B). However, in 2015, test weight values below the threshold were observed and discounts applied to programs that included the $\mathrm{C} 4, \mathrm{C} 5$, and C8 SPACE-TRT combinations (Fig. 5F). The highest penalties ( $t w l$ ranging from $\$ 3.2$ to $4.72 \mathrm{MT}^{-1}$ ) were applied to programs with

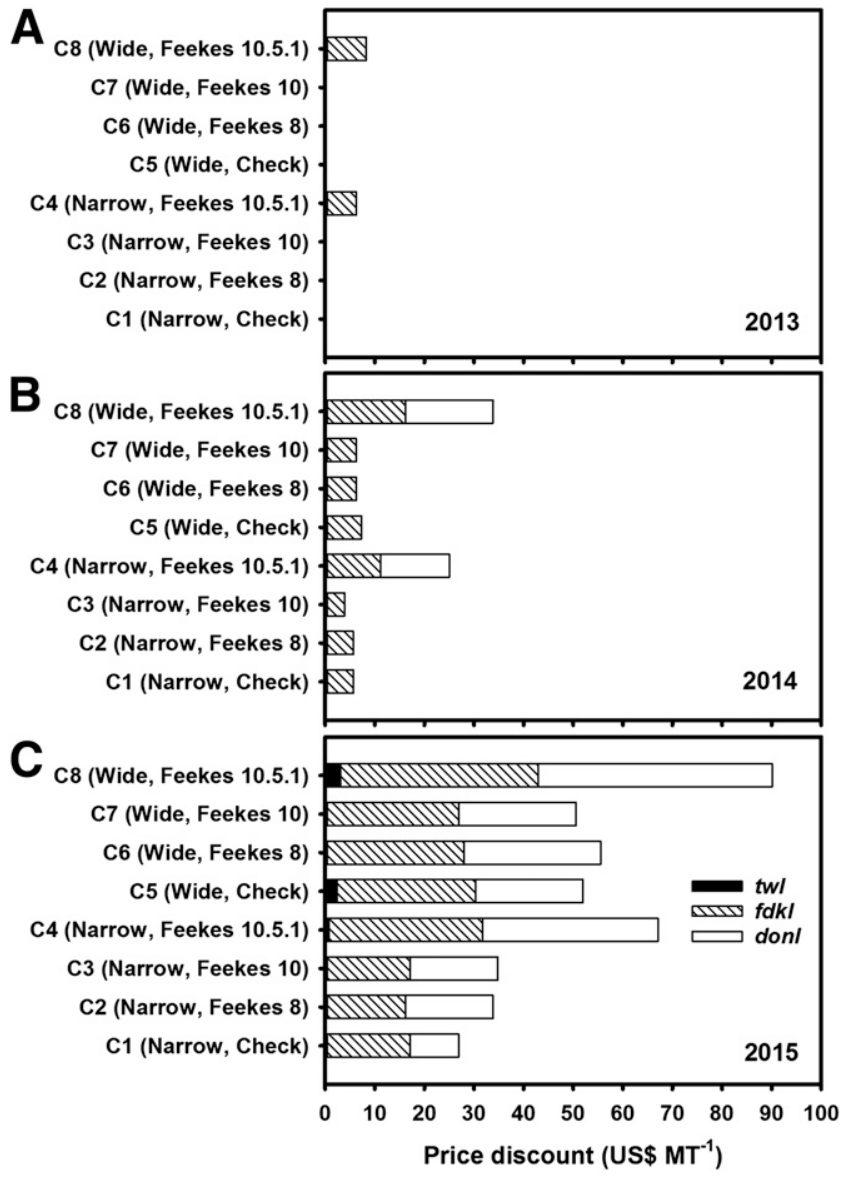

Fig. 6. Estimated price discounts for test weight below $746.6 \mathrm{~kg} / \mathrm{cm}^{3}(t w)$, Fusarium damaged kernels above $1 \%$ (fdk), and deoxynivalenol grain contamination above 2 ppm (donl) for different combinations of fungicide treatment $\times$ row spacing applied to soft red winter wheat cultivar Hopewell in Wooster, OH, in 2013, 2014, and 2015. $\mathrm{C} 1$ = narrow row spacing and untreated check; $\mathrm{C} 2=$ narrow row spacing and application of the fungicide Prosaro ( $19 \%$ tebuconazole $+19 \%$ prothioconazole) at $475 \mathrm{ml} \mathrm{ha}^{-1}$ at Feekes 8 (flag leaf emergence); $\mathrm{C} 3=$ narrow row and Prosaro at Feekes 10 (boot); C4 = narrow row and Prosaro at Feekes 10.5.1 (anthesis); C5 = wide row and untreated check; $\mathrm{C} 6=$ wide row and Prosaro at Feekes 8; $\mathrm{C} 7=$ wide row and Prosaro at Feekes 10; and $C 8=$ wide row and Prosaro at Feekes 10.5.1. $\mathrm{C} 4$ and $\mathrm{C} 8$ were inoculated at anthesis with a spore suspension of $F$. graminearum.
C8 (test weight between 728 and $735 \mathrm{~kg} \mathrm{~m}^{-3}$ ). Programs that included $\mathrm{C} 4$ and $\mathrm{C} 5$ received $t w l$ ranging from $\$ 0.80$ to $3.2 \mathrm{MT}^{-1}$ (Fig. 6C).

In 2013, only programs that included the $\mathrm{C} 4$ and C8 SPACE-TRT combinations (inoculated plots with the highest levels of FHB) had quantifiable levels of FDK and DON. Consequently, these programs received price penalties ( $f d k l$ values) of $\$ 6.3$ and $8.3 \mathrm{MT}^{-1}$, respectively (Fig. 6A), for having FDK above the $1 \%$ threshold (Salgado et al. 2011). However, none of these programs were penalized for high DON, since they all had levels below the $2 \mathrm{ppm}$ threshold (Fig. 2). In 2014, price discounts for FDK above the threshold ( $f d k l$ ranging from $\$ 3.9$ to $16.1 \mathrm{MT}^{-1}$ ) were applied to all programs, but only programs with $\mathrm{C} 4$ and $\mathrm{C} 8$ ( $F$. graminearum inoculate plots) were penalized for DON above $2 \mathrm{ppm}$ (donl of $\$ 13.8$ and $17.7 \mathrm{MT}^{-1}$, respectively) (Fig. 6B). In 2015, the year with the highest levels of FHB (Fig. 2), all programs were penalized for having high FDK and DON, with $f d k l$ ranging from $\$ 16.1$ to $39.8 \mathrm{MT}^{-1}$ and donl from 9.8 to $47.4 \mathrm{MT}^{-1}$. Programs with wide row spacing and the highest mean FDK and DON (C5, C6, C7, or C8) received the highest price discounts ( $\$ 27$ to $39.8 \mathrm{MT}^{-1}$ for FDK and 22 to $47.4 \mathrm{MT}^{-1}$ for DON) when compared with narrow-row programs $\left(\$ 16.1\right.$ to $30.9 \mathrm{MT}^{-1}$ for FDK and 9.8 to $35.4 \mathrm{MT}^{-1}$ for DON) (Fig. 6C).

Net cash income. Using the information in Table 5 and equations 4 and 6 , NCI values were estimated at three grain prices $(\$ 118,197$, and $276 \mathrm{MT}^{-1}$ ) and three $\mathrm{N}$ rates (Table 6). For instance, in 2013, at a grain price of $\$ 118 \mathrm{MT}^{-1}$, NCI was estimated for $\mathrm{C} 4$ at the low $\mathrm{N}$ rate as $Y\left(4.58 \mathrm{MT} \mathrm{ha}^{-1}\right) \times\left(P\left[\$ 118 \mathrm{MT}^{-1}\right]-d c t[\$ 6.3\right.$ $\left.\left.\mathrm{MT}^{-1}\right]\right)-$ Cost $\left[\$ 258.2 \mathrm{ha}^{-1}\right]=\$ 253.5 \mathrm{ha}^{-1}$. NCI varied among years, ranging from $\$ 239.4$ to $\$ 1,189.1 \mathrm{ha}^{-1}$ in $2013, \$ 113.4$ to $\$ 1,159.3 \mathrm{ha}^{-1}$ in 2014 , and $\$-159.6$ to $\$ 990.1 \mathrm{ha}^{-1}$ in 2015 . By definition, NCI increased with grain price, and at any given price, the highest NCIs were obtained for management programs with the highest yields and lowest $d c t$ (Tables 5 and 6, Fig. 6). In 2013, the year in which the effect of row spacing on grain yield was not statistically significant (Table 2), wide-row programs had higher NCI than narrow-row programs for a given fungicide treatment (Table 6) at all tested grain prices. However, the opposite was observed in 2014 and 2015, with narrow-row programs having consistently higher NCI than wide-row programs for any given fungicide treatment, particularly at grain prices of $\$ 197$ and $\$ 276 \mathrm{MT}^{-1}$. For instance, in 2014, narrowrow programs had between $\$ 5.7$ and $\$ 108.0 \mathrm{ha}^{-1}$ higher NCI than wide-row programs at grain prices above $\$ 197 \mathrm{MT}^{-1}$. The corresponding differences in 2015 were between $\$ 3.21$ and $\$ 238.1$ ha $^{-1}$ (Table 6).

Economic benefit. Using C1_S (narrow row, no fungicide, and standard $\mathrm{N}$ rate) as the reference, economic benefit (EB) was estimated for each management program as the difference in NCI between that program $\left(N C I_{P R O G}\right)$ and the reference $\left(N C I_{R E F}\right)$ (equation 3). In 2013, $N C I_{P R O G}$ was higher than $N C I_{R E F}(\$ 265.5$, $\$ 608.8$, and $\$ 952.0 \mathrm{ha}^{-1}$, at the low, medium, and high grain prices; Table 6) for most of the programs, particularly at grain prices of $\$ 197$ and $\$ 276 \mathrm{MT}^{-1}$ (Fig. 7A-C). Notable exceptions were observed at the lowest tested grain price $\left(\$ 118 \mathrm{MT}^{-1}\right)$ for programs with the narrow row spacing and the high $\mathrm{N}$ rate $\left(\mathrm{C} 1 \_\mathrm{H}, \mathrm{C} 2 \_\mathrm{H}, \mathrm{C} 3 \_\mathrm{H}\right.$, and C4_H) and narrow-row programs that received price discounts for having FDK above the 1\% threshold (C4_L and C4_S) (Table 6, Fig. 7A). The reference program was also more economically beneficial than C1_H (Fig. 7A-C). Management programs consisting of wide row spacing combined with high or standard $\mathrm{N}$ rates and a Prosaro application were among the four most economically beneficial programs in 2013 (Fig. 7A-C).

In 2014 and 2015, years in which all management programs suffered price discounts due to relatively inferior grain quality, $N C I_{P R O G}$ values were almost always lower that the reference NCI values $\left(N C I_{R E F}\right)$, meaning that the reference or standard management program (C1_S; narrow row, no fungicide, and standard $\mathrm{N}$ rate) was generally more economically beneficial than the modified programs (Fig. 7D-I). For instance, at the low grain price $\left(\$ 118 \mathrm{MT}^{-1}\right)$ all but seven of the modified programs in 2014 (Fig. 7D) and one in 2015 had lower NCI than $N C I_{R E F}$ (Fig. 7G). Similar trends were observed at the two high grain prices in 2014 and 2015 (Fig. 7E, F, H, and I), with only a few of the modified programs being more economically 
beneficial than $\mathrm{C} 1 \_S$. In general, relative to $\mathrm{C} 1 \_\mathrm{S}$, the least economically beneficial programs included those that suffered the greatest price discounts due to high FDK and DON (programs with C8 and C4 in Fig. 7D-I). Conversely, programs that suffered the lowest price discounts, particularly those with relatively high yield due to high $\mathrm{N}$ rates and narrow row spacing, were the most economically beneficial when grain prices were $197 \mathrm{MT}^{-1}$ or greater (Fig. 7E, F, H, and I).

\section{Discussion}

There is a fairly large body of data on the effects of row spacing, planting density, and nitrogen rates on wheat grain yield and quality (Hussain et al. 2012, 2016; Lafond 1994; Mali and Choudhary 2012; Porter and Khalilian 1995; Sandler et al. 2015) and the effect of nitrogen on diseases (Devadas et al. 2014; Dordas 2008; May et al. 2014). However, there are fewer published reports on the specific effects of row spacing on pests and diseases (Broscious et al. 1985; Champion et al. 1998; Kolb et al. 2012), and none of these were based on results from studies on SRWW in Ohio. Here we present findings from a 3-year study documenting the effects of row spacing and nitrogen application rate on FHB and leaf rust, two of the most economically important diseases of wheat in Ohio and other parts of the Midwest. In addition, we provide evidence of how the profitability of wheat managed using different combinations of $\mathrm{N}$ rate, row spacing, and fungicide treatment could be influenced by FHB and leaf rust. Our results showed that all measures of FHB and associated grain quality traits (test weight and DON) were affected by row spacing, with wide-row plots having significantly higher mean levels of FHB and DON than narrow-row plots in 2014 and 2015, and numerically higher levels in 2013, both with and without artificial inoculation (nonsignificant TRT $\times$ SPACE interactions). For leaf rust, similar trends were observed in 2013 and
2014, but the differences were not statistically significant. Leaf blotch (Septoria and Stagonospora) intensity was not high enough for us to evaluate the row-spacing effect, but results from a study in Maryland also reported consistently higher Stagonospora leaf blotch severity in wide-row $(20 \mathrm{~cm})$ compared with narrow-row $(10 \mathrm{~cm})$ wheat plots (Orth and Grybauskas 1994).

The fact that row spacing affected disease development is not at all surprising, but our findings are somewhat contrary to what one would expect given that a closed and humid canopy, typical of narrow row spacing, is often thought to be more favorable for disease development than an open and supposedly drier wide-row canopy. From these results, it seems reasonable to think that either the microclimate in narrow-row plots was no more favorable for FHB development than in wide-row plots or that the difference in microclimate between the two types of plots was not the primary driver of differences in disease development. Orth and Grybauskas (1994) speculated that lower disease severity in dense, narrow-row wheat was likely due to a physical separation between in-field inoculum and the upper leaves and spikes. However, since our plots were established in tilled fields with very little host crop residue, differential upward dispersal of inoculum from in-field residue was unlikely the reason for differences in FHB and DON between wide- and narrow-row plots. Other possible explanations could be differences in flowering synchrony and spore deposition between wide- and narrow-row plots. Stand count data provide some support for the former hypothesis, as wide-row plots had higher tiller and head counts per meter of row than narrowrow plots (data not shown), suggesting that more secondary tillers developed in the former than in the latter plots. With more secondary, and consequently, late-flowering tillers, crop development was likely more asynchronous in wide- than in narrow-row wheat, leading to a wider infection window for the FHB pathogen. However,

Table 5. Estimated grain yields, price discounts, and management costs for different row spacing $\times$ fungicide treatment combinations at low, standard, and high $\mathrm{N}$ rates from field experiments conducted in Wooster, $\mathrm{OH}$, in 2013, 2014, and 2015

\begin{tabular}{|c|c|c|c|c|c|c|c|c|c|c|}
\hline \multirow[b]{3}{*}{ Year } & \multirow[b]{3}{*}{ Spacing $\times$ Treatment $^{\mathbf{a}}$} & \multirow{2}{*}{\multicolumn{3}{|c|}{$\frac{\text { Grain yield }^{\mathrm{b}}}{\left(Y, \text { MT ha }^{-1}\right)}$}} & \multirow{2}{*}{\multicolumn{3}{|c|}{$\begin{array}{r}\text { Price discount }^{\mathbf{b}} \\
\left(\text { dct }, \$ \mathrm{MT}^{-1}\right)\end{array}$}} & \multirow{2}{*}{\multicolumn{3}{|c|}{$\frac{\text { Management cost }^{\mathrm{b}}}{\left(\text { Cost }, \$ \mathrm{ha}^{-1}\right)}$}} \\
\hline & & & & & & & & & & \\
\hline & & $\mathbf{L}$ & $\mathbf{S}$ & $\mathbf{H}$ & $\mathbf{L}$ & $\mathbf{S}$ & $\mathbf{H}$ & $\mathbf{L}$ & $\mathbf{S}$ & $\mathbf{H}$ \\
\hline \multirow[t]{8}{*}{2013} & C1 (Narrow, Check) & 4.25 & 4.34 & 4.40 & 0.00 & 0.00 & 0.00 & 197.21 & 247.15 & $\overline{277.11}$ \\
\hline & C2 (Narrow, Feekes 8) & 4.58 & 4.78 & 4.89 & 0.00 & 0.00 & 0.00 & 258.21 & 308.15 & 338.11 \\
\hline & C3 (Narrow, Feekes 10) & 4.62 & 4.89 & 5.05 & 0.00 & 0.00 & 0.00 & 258.21 & 308.15 & 338.11 \\
\hline & C4 (Narrow, Feekes 10.5.1) & 4.58 & 4.98 & 5.22 & 6.30 & 6.30 & 6.30 & 258.21 & 308.15 & 338.11 \\
\hline & C5 (Wide, Check) & 4.08 & 4.25 & 4.36 & 0.00 & 0.00 & 0.00 & 106.70 & 156.64 & 186.60 \\
\hline & C6 (Wide, Feekes 8) & 4.16 & 4.63 & 4.91 & 0.00 & 0.00 & 0.00 & 167.70 & 217.64 & 247.60 \\
\hline & C7 (Wide, Feekes 10) & 4.39 & 4.90 & 5.21 & 0.00 & 0.00 & 0.00 & 167.70 & 217.64 & 247.60 \\
\hline & C8 (Wide, Feekes 10.5.1) & 4.41 & 4.78 & 4.99 & 8.27 & 8.27 & 8.27 & 167.70 & 217.64 & 247.60 \\
\hline \multirow[t]{8}{*}{2014} & C1 (Narrow, Check) & 4.52 & 4.84 & 5.28 & 5.71 & 5.71 & 5.71 & 197.21 & 247.15 & 317.06 \\
\hline & C2 (Narrow, Feekes 8) & 4.72 & 5.03 & 5.48 & 5.71 & 5.71 & 5.71 & 258.21 & 308.15 & 378.06 \\
\hline & C3 (Narrow, Feekes 10) & 4.89 & 5.21 & 5.65 & 3.94 & 3.94 & 3.94 & 258.21 & 308.15 & 378.06 \\
\hline & C4 (Narrow, Feekes 10.5.1) & 4.52 & 4.84 & 5.28 & 25.00 & 25.00 & 25.00 & 258.21 & 308.15 & 378.06 \\
\hline & C5 (Wide, Check) & 4.05 & 4.37 & 4.81 & 7.28 & 7.28 & 7.28 & 106.70 & 156.64 & 226.55 \\
\hline & C6 (Wide, Feekes 8) & 4.19 & 4.50 & 4.95 & 6.30 & 6.30 & 6.30 & 167.70 & 217.64 & 287.55 \\
\hline & C7 (Wide, Feekes 10) & 4.20 & 4.52 & 4.96 & 6.30 & 6.30 & 6.30 & 167.70 & 217.64 & 287.55 \\
\hline & C8 (Wide, Feekes 10.5.1) & 4.14 & 4.46 & 4.90 & 33.86 & 33.86 & 33.86 & 167.70 & 217.64 & 287.55 \\
\hline \multirow[t]{8}{*}{2015} & C1 (Narrow, Check) & 4.17 & 4.49 & 4.94 & 26.97 & 26.97 & 26.97 & 197.21 & 247.15 & 317.06 \\
\hline & C2 (Narrow, Feekes 8) & 4.17 & 4.79 & 5.65 & 33.86 & 33.86 & 33.86 & 258.21 & 308.15 & 378.06 \\
\hline & C3 (Narrow, Feekes 10) & 4.26 & 4.75 & 5.42 & 34.85 & 34.85 & 34.85 & 258.21 & 308.15 & 378.06 \\
\hline & C4 (Narrow, Feekes 10.5.1) & 4.06 & 4.44 & 4.98 & 68.70 & 67.91 & 67.14 & 258.21 & 308.15 & 378.06 \\
\hline & C5 (Wide, Check) & 3.67 & 3.82 & 4.02 & 52.75 & 52.75 & 51.96 & 106.70 & 156.64 & 226.55 \\
\hline & C6 (Wide, Feekes 8) & 4.01 & 4.33 & 4.79 & 55.51 & 55.51 & 55.51 & 167.70 & 217.64 & 287.55 \\
\hline & C7 (Wide, Feekes 10) & 4.08 & 4.37 & 4.78 & 50.59 & 50.59 & 50.59 & 167.70 & 217.64 & 287.55 \\
\hline & C8 (Wide, Feekes 10.5.1) & 3.84 & 4.15 & 4.59 & 91.72 & 90.94 & 90.15 & 167.70 & 217.64 & 287.55 \\
\hline
\end{tabular}

${ }^{a} \mathrm{C} 1=$ narrow row spacing and untreated check; $\mathrm{C} 2=$ narrow row spacing and application of the fungicide Prosaro (19\% tebuconazole $+19 \%$ prothioconazole) at $475 \mathrm{ml} / \mathrm{ha}$ at Feekes 8 (flag leaf emergence); C3 = narrow row and Prosaro at Feekes 10 (boot); C4 = narrow row and Prosaro at Feekes 10.5 .1 (anthesis); C5 = wide row and untreated check; $\mathrm{C} 6=$ wide row and Prosaro at Feekes 8; $\mathrm{C} 7=$ wide row and Prosaro at Feekes 10; and $\mathrm{C} 8=$ wide row and Prosaro at Feekes 10.5 .1 . $\mathrm{C} 4$ and $\mathrm{C} 8$ were inoculated at anthesis with spores of $F$. graminearum.

${ }^{\mathrm{b}}$ Estimated grain yields based on the parameters in Table 3, price discounts (sum of price penalties due to DON and FDK above and test weight below predetermined thresholds [Salgado et al. 2011]), and management costs (sum of seed [ $\$ 116.8 \mathrm{ha}^{-1}$ for narrow rows and $\$ 66.7 \mathrm{ha}^{-1}$ for wide rows], $\mathrm{N}$ at $\$ 0.89 \mathrm{Kg}^{-1}$, fungicide plus application costs at $\$ 61 \mathrm{ha}^{-1}$, and cost for maintaining a narrow-row planter $\left.\left[40.43 \mathrm{ha}^{-1}\right]\right)$ were estimated at low $\left(\mathrm{L}=44.83 \mathrm{~kg}\right.$ ha $\left.{ }^{-1}\right)$, standard $(\mathrm{S}=$ $\left.100.88 \mathrm{~kg} \mathrm{ha}^{-1}\right)$, and high $\left(\mathrm{H}=134.50 \mathrm{~kg} \mathrm{ha}^{-1}\right.$ in 2013 and $179.34 \mathrm{~kg} \mathrm{ha}^{-1}$ in 2014 and 2015) $\mathrm{N}$ rates. 
follow-up experiments are needed to quantify relationships among in-canopy spore movement and deposition, FHB intensity, and crop development in narrow- and wide-row wheat plots, with and without an in-field source of inoculum.

Under the conditions of this study, $\mathrm{N}$ did not have a significant effect on any measure of FHB or DON. Our results are consistent with those reported by Fauzi and Paulitz (1994), May et al. (2014), Oldenburg et al. (2007), Teich and Hamilton (1985), and Yoshida et al. (2008), but contrary to those reported by Heier et al. (2005), Teich et al. (1987), and Lemmens et al. (2004). Such variation in the effect of $\mathrm{N}$ on FHB and DON could be due to several factors. Yoshida et al. (2008) hypothesized that timing of $\mathrm{N}$ application (green-up versus postheading) may affect FHB and DON; Teich et al. (1987) demonstrated that FHB response to N varied among cultivars; Subedi et al. (2007) speculated that the effect of N on FHB was influenced by soil type (sandy versus heavy); and Lemmens et al. (2004) provided data showing that the amount and type of $\mathrm{N}$ fertilizer (organic versus mineral) influenced FHB severity and DON contamination. In the latter study, the authors showed that increasing total $\mathrm{N}$ from 0 to $160 \mathrm{~kg} \mathrm{ha}^{-1}$ (at $40 \mathrm{~kg} \mathrm{ha}^{-1}$ increments) led to progressively higher FHB severity, with results suggesting that the rate of FHB increase per kg increase in $\mathrm{N}$ was greater with mineral than with organic sources of N. However, all of the aforementioned factors as well as wheat market class and growing conditions varied among the studies cited above, making it difficult to ascertain the true effect of $\mathrm{N}$ on FHB and DON and the mechanisms involved.

Contrary to what was observed for FHB, and often reported for leaf blotching diseases of wheat (van Ginkel et al. 1999), the effect of nitrogen on cereal rusts is better understood, and seems to be fairly consistent across cereal species. As was observed in our study, rust severity often increases with increasing N (Danial and Parlevliet 1995; Devadas et al. 2014; Howard et al. 1994), and the response appears to be more closely related to the nutritional requirement of rust pathogens (Dordas 2008) than to mere increases in canopy humidity due to lush vegetative growth. Dordas (2008) explained that relationships between diseases caused by obligate pathogens (like Puccinia triticina) and $\mathrm{N}$ are often positive because increasing $\mathrm{N}$ leads to succulent plant tissues that are more susceptible to infection, weaker structural and biochemical plant defense systems, and more amino acid in the apoplast as substrate for fungal development. According to Murray et al. (2005), adult plant resistance to stripe rust was delayed, and Robert et al. $(2002,2004)$ reported that the production and infection efficiency (based on lesion density at a known spore concentration) of $P$. triticina urediniospores increased in wheat with high $\mathrm{N}$ content.

The magnitude of the rust response to $\mathrm{N}$ (based on the slopes for relationships between rust and $\mathrm{N}$ ) varied from one year to another and was affected by fungicide treatment, likely reflecting variations in disease onset and baseline severity among years. Although high $\mathrm{N}$ rates may favor growth and sporulation of the rust fungus and make plants more susceptible to infection, a well-timed application of a fungicide helps to counteract these effects by preventing spore germination, germ tube development, or infection. In particular, DMIs such as $19 \%$ tebuconazole $+19 \%$ prothioconazole prevent infection and disease development by inhibiting the biosynthesis of ergosterol, which is an important component of fungal cell membrane (Amarasinghe et al. 2013; Liu et al. 2010; Parker et al. 2011). In Ohio and other parts of the Midwest where rust development is a function of when and how much spores are blown in from southern states, fungicide efficacy is strongly dependent on when applications are made relative to spore influx and infection. In 2013 and 2014 when disease onset was relatively late (after boot), slopes for the $\mathrm{N} \times$ rust relationship were not significantly different from zero $(P>0.05)$ for the Feekes 10 and 10.5.1 fungicide treatments, indicating that both timings were equally effective across all tested levels of $\mathrm{N}$, and consequently, baseline levels of disease. However, for the Feekes 8 treatments, applied well before infection (based on visual symptoms), slopes were significantly greater than zero, reflecting the aforementioned effects of $\mathrm{N}$ on rust and the fact that applications made too early were less effective, particularly under conditions favorable for disease development. On the

Table 6. Estimated net cash income $(\mathrm{NCI})$ for different wheat row spacing $\times$ fungicide treatment combinations at low $(\mathrm{L})$, standard $(\mathrm{S})$, and high $(\mathrm{H}) \mathrm{N}$ rates from field experiments conducted in Wooster, $\mathrm{OH}$, in 2013, 2014, and 2015

\begin{tabular}{|c|c|c|c|c|c|c|c|c|c|c|}
\hline \multirow[b]{2}{*}{ Year } & \multirow[b]{2}{*}{ Spacing $\times$ Treatment } & \multicolumn{3}{|c|}{$\$ 118 \mathrm{MT}^{-1}$} & \multicolumn{3}{|c|}{$\$ 197 \mathrm{MT}^{-1}$} & \multicolumn{3}{|c|}{$\$ 276 \mathrm{MT}^{-1}$} \\
\hline & & $\mathbf{L}$ & $\mathbf{S}$ & $\mathbf{H}$ & $\mathbf{L}$ & $\mathbf{S}$ & $\mathbf{H}$ & $\mathbf{L}$ & $\mathbf{S}$ & $\mathbf{H}$ \\
\hline \multirow[t]{8}{*}{2013} & C1 (Narrow, Check) & 304.22 & 265.52 & 242.31 & 639.93 & 608.75 & 590.05 & 975.63 & 951.98 & 937.79 \\
\hline & C2 (Narrow, Feekes 8) & 282.57 & 255.57 & 239.37 & 644.62 & 632.98 & 625.99 & $1,006.67$ & $1,010.38$ & $1,012.60$ \\
\hline & C3 (Narrow, Feekes 10) & 286.74 & 268.36 & 257.34 & 651.57 & 654.33 & 655.99 & $1,016.40$ & $1,040.30$ & $1,054.63$ \\
\hline & C4 (Narrow, Feekes 10.5.1) & 253.45 & 248.33 & 245.26 & 615.32 & 641.90 & 657.85 & 977.18 & $1,035.47$ & $1,070.43$ \\
\hline & C5 (Wide, Check) & 374.20 & 345.38 & 328.10 & 696.16 & 681.48 & 672.68 & $1,018.11$ & $1,017.59$ & $1,017.27$ \\
\hline & C6 (Wide, Feekes 8) & 323.00 & 328.27 & 331.43 & 651.52 & 693.76 & 719.08 & 980.04 & $1,059.24$ & $1,106.74$ \\
\hline & C7 (Wide, Feekes 10) & 349.79 & 360.34 & 366.66 & 696.24 & 747.29 & 777.90 & $1,042.69$ & $1,134.24$ & $1,189.14$ \\
\hline & C8 (Wide, Feekes 10.5.1) & 316.40 & 306.33 & 300.28 & 664.93 & 683.56 & 694.73 & $1,013.46$ & $1,060.79$ & $1,089.18$ \\
\hline \multirow{8}{*}{2014} & C1 (Narrow, Check) & 310.71 & 296.38 & 276.31 & 668.04 & 678.76 & 693.77 & $1,025.38$ & $1,061.15$ & $1,111.22$ \\
\hline & C2 (Narrow, Feekes 8) & 271.34 & 257.01 & 236.95 & 643.90 & 654.62 & 669.63 & $1,016.45$ & $1,052.23$ & $1,102.30$ \\
\hline & C3 (Narrow, Feekes 10) & 299.51 & 285.74 & 266.47 & 685.80 & 697.08 & 712.87 & $1,072.09$ & $1,108.42$ & $1,159.28$ \\
\hline & C4 (Narrow, Feekes 10.5.1) & 162.51 & 142.06 & 113.43 & 519.89 & 524.49 & 530.94 & 877.27 & 906.93 & 948.44 \\
\hline & C5 (Wide, Check) & 342.12 & 327.29 & 306.53 & 662.36 & 672.58 & 686.89 & 982.59 & $1,017.87$ & $1,067.25$ \\
\hline & C6 (Wide, Feekes 8) & 299.89 & 285.37 & 265.04 & 630.59 & 641.12 & 655.87 & 961.29 & 996.88 & $1,046.69$ \\
\hline & C7 (Wide, Feekes 10) & 301.79 & 287.27 & 266.94 & 633.83 & 644.37 & 659.11 & 965.88 & $1,001.46$ & $1,051.28$ \\
\hline & C8 (Wide, Feekes 10.5.1) & 180.57 & 157.31 & 124.75 & 507.56 & 509.36 & 511.87 & 834.56 & 861.40 & 898.98 \\
\hline \multirow[t]{8}{*}{2015} & C1 (Narrow, Check) & 182.47 & 161.58 & 132.33 & 511.96 & 516.28 & 522.34 & 841.46 & 870.99 & 912.34 \\
\hline & C2 (Narrow, Feekes 8) & 92.53 & 94.54 & 97.36 & 421.84 & 472.63 & 543.74 & 751.14 & 850.72 & 990.11 \\
\hline & C3 (Narrow, Feekes 10) & 96.29 & 86.41 & 72.59 & 433.09 & 461.28 & 500.74 & 769.89 & 836.15 & 928.90 \\
\hline & C4 (Narrow, Feekes 10.5.1) & -57.93 & -85.52 & -124.82 & 263.01 & 265.59 & 268.53 & 583.95 & 616.70 & 661.88 \\
\hline & C5 (Wide, Check) & 132.83 & 92.39 & 38.96 & 422.84 & 393.90 & 356.58 & 712.84 & 695.42 & 674.20 \\
\hline & C6 (Wide, Feekes 8) & 82.58 & 53.02 & 11.63 & 399.00 & 395.18 & 389.84 & 715.41 & 737.35 & 768.06 \\
\hline & C7 (Wide, Feekes 10) & 107.43 & 77.10 & 34.64 & 429.87 & 422.52 & 412.23 & 752.31 & 767.94 & 789.81 \\
\hline & C8 (Wide, Feekes 10.5.1) & -66.87 & -105.28 & -159.60 & 236.23 & 222.76 & 203.34 & 539.33 & 550.80 & 566.27 \\
\hline
\end{tabular}

${ }^{\mathrm{a}} \mathrm{C} 1=$ narrow row spacing and untreated check; $\mathrm{C} 2=$ narrow row spacing and application of the fungicide Prosaro (19\% tebuconazole $+19 \%$ prothioconazole) at a rate of $475 \mathrm{ml} \mathrm{ha}^{-1}$ at Feekes 8 (flag leaf emergence); $\mathrm{C} 3=$ narrow row and Prosaro at Feekes 10 (boot); C4 = narrow row and Prosaro at Feekes 10.5 .1 (anthesis); $\mathrm{C} 5=$ wide row and untreated check; $\mathrm{C} 6=$ wide row and Prosaro at Feekes 8; $\mathrm{C} 7=$ wide row and Prosaro at Feekes 10; and C8 $=$ wide row and Prosaro at Feekes 10.5.1; NCI was estimated for each grain price at low $\left(\mathrm{L}=44.8 \mathrm{~kg} \mathrm{ha}^{-1}\right)$, standard $\left(\mathrm{S}=100.9 \mathrm{~kg} \mathrm{ha}^{-1}\right)$, and high $\left(\mathrm{H}=134.5 \mathrm{~kg} \mathrm{ha}^{-1}\right.$ in 2013 and $179.3 \mathrm{~kg} \mathrm{ha}{ }^{-1}$ in 2014 and 2015) $\mathrm{N}$ rates. 
other hand, when the onset of rust was relatively early (before boot) and baseline severity remained low (as was the case in 2015), all treatments effectively controlled the disease across all tested $\mathrm{N}$ levels (slopes for treated plots were not significantly different from zero).

The observed grain yield and test weight responses to $\mathrm{N}$ are consistent with what is commonly reported in the literature (Denys et al. 2006; Devadas et al. 2014; May et al. 2014), and the physiology of grain yield response in wheat has been well documented (Frederick and Bauer 1999; Stone and Savin 1999). Therefore, it is not our intention to discuss these at length in this paper. However, contrary to what is often reported for relationships between wheat yield and N (Denys et al. 2006; Devadas et al. 2014; Gandorfer and Rajsic 2008; Howard et al. 1994), under the conditions of this study, yield did not reach a peak or plateau in most cases; straight-line $\mathrm{N}$ response models provided the best fit to our data in 2013 and 2015 and fitted just as well as quadratic response models in 2014. This could have been due, at least in part, to nitrogen loss. However, as discussed to by Frederick and Bauer (1999), wheat yield is not only a function of nutrient uptake and metabolism, it is also dependent on photosynthesis and respiration, carbon partitioning, leaf senescence, and plant water relations. Thus, cultural practices and stresses (biotic and abiotic) that affect one or more of these processes, such as the negative effects of diseases on photosynthesis (Gaunt 1995; Robert et al.
2005) and leaf senescence (Gooding 2007; Gooding et al. 2000), may prevent a crop from reaching its full yield potential even if nutrients are not limiting.

We observed that the magnitude of the yield response to $\mathrm{N}$ (based on regression slopes and/or intercepts) varied among fungicide treatment $\times$ row spacing combinations, likely reflecting, at least in part, the fact that the treatments varied in their efficacy against leaf rust, row spacing affected FHB development, and both rust and FHB negatively affected grain yield (Gaunt 1995; McMullen et al. 2012; Salgado et al. 2015). Indeed, in 2013 and 2015, years with the highest levels of leaf rust and FHB, respectively, the rates of yield increase per unit increase in $\mathrm{N}$ for a given row spacing were higher in fungicide treated plots than the untreated check. This was probably because the fungicide treatments may have contributed to the yield response by extending green flag leaf area duration and the grain fill period (Dimmock and Gooding 2002). The health of the flag leaf and spike is important for grain yield and quality (Ruske et al. 2003; Simpson 1968) as the greatest contributors of photoassimilates for grain-fill are the blade (45\%) and sheath (25\%) of the flag leaf and the glumes of the spike (25\%) (Lupton 1972).

Although higher $\mathrm{N}$ rates resulted in higher mean grain yield and test weight, and planting wheat in $38-\mathrm{cm}$ rows helped to reduce production cost, integrating these two management strategies was not

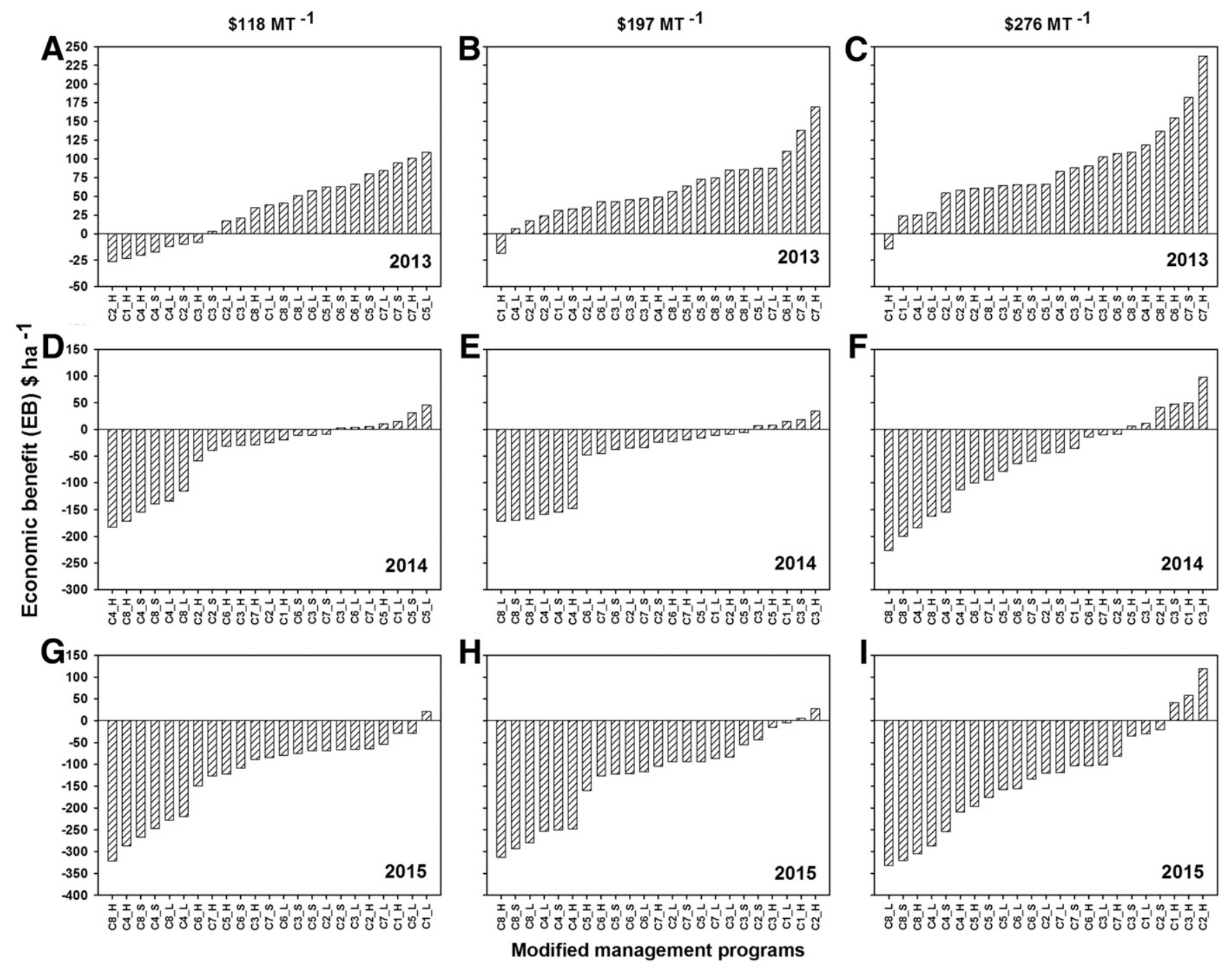

Fig. 7. Estimated economic benefits (EB) of different management programs (combinations of fungicide treatment, row spacing, and nitrogen rates) applied to soft red winter wheat cultivar Hopewell in Wooster, OH, in 2013, 2014, and 2015. C1 = narrow row spacing and untreated check; $\mathrm{C} 2$ = narrow row spacing and application of the fungicide Prosaro (19\% tebuconazole $+19 \%$ prothioconazole) at $475 \mathrm{ml} \mathrm{ha}^{-1}$ at Feekes 8 (flag leaf emergence); $\mathrm{C} 3=$ narrow row and Prosaro at Feekes 10 (boot); $\mathrm{C} 4=$ narrow row and Prosaro at Feekes 10.5.1 (anthesis); $\mathrm{C} 5=$ wide row and untreated check; $\mathrm{C} 6=$ wide row and Prosaro at Feekes $8 ; \mathrm{C} 7=$ wide row and Prosaro at Feekes $10 ;$ and $\mathrm{C} 8=$ wide row and Prosaro at Feekes 10.5.1. C4 and C8 were inoculated at anthesis with a spore suspension of $F$. graminearum. $L=$ low N rate $\left(44.8 \mathrm{~kg} \mathrm{ha}^{-1}\right), \mathrm{S}=$ standard N rate $\left(100.8 \mathrm{~kg} \mathrm{ha}{ }^{-1}\right)$, and H $=$ high $\mathrm{N}$ rate (134.5 kg ha ${ }^{-1}$ in 2013 and $179.3 \mathrm{~kg} \mathrm{ha}^{-1}$ in 2014 and 2015). EB values were estimated at three grain prices using equations 3 to 6 . 
always economically beneficial under the conditions of this study. Only in 2013, the year in which grain yield and test weight were not significantly different between row spacings and the FHB severity was the lowest, were most of the modified management programs more economically beneficial than the reference program (standard $\mathrm{N}$ rate, no fungicide, and narrow row spacing). This was particularly true at grain prices of $\$ 197$ and $\$ 276 \mathrm{MT}^{-1}$. The two more economically beneficial programs at $\$ 197$ and $\$ 276 \mathrm{MT}^{-1}$ consisted of widerow plots treated with nitrogen at the standard or highest tested rates and Prosaro at Feekes 10. These results suggest that growing conditions in 2013 likely favored greater tiller development in wide-row plots than in narrow-row plots, thus resulting in comparable yields per hectare between spacings and greater economic benefit in (widerow) programs with lower seed and machine-related costs. Indeed, mean head-bearing tiller count per meter of row (data not shown) was higher in wide-row plots (177) than in narrow-row plots (148). However, with only four 6.1-meter-long rows in each $9.2 \mathrm{~m}^{2}$ widerow plot compared with seven rows in narrow-row plots, the observed mean difference in head-bearing tiller was likely not the only explanation for comparable yields between the two spacings, as narrow-row plots still had approximately $30 \%$ more heads per hectare than widerow plots. We hypothesize that increases in other yield components in wide-row plots, such as the number and size of the kernels per spike, as reported by reported by Lafond (1994) and Porter and Khalilian (1995), also contributed to the observed yield response.

As was the case in 2013, mean tiller counts per meter of row were also higher in wide-row plots than in narrow-row plots in 2014 and 2015 , but contrary to what was observed in 2013, mean grain yield (and test weight) was approximately $10 \%$ lower in wide- than in narrow-row plots in the latter two years. These results are comparable to those reported by Hussain et al. $(2012,2016)$ based on research conducted using low-tillering cultivars and under environmental stress conditions. Another major difference among the growing seasons was FHB intensity, which was higher in 2014 and 2015 than in 2013. Since FHB causes shriveled and light-weight kernels (McMullen et al. 2012) and our results showed that FHB intensity was higher in wide- than in narrow-row plots, this disease likely reduced kernel number and size per spike, preventing these yield components from compensating for lower tiller population per hectare in wide row spacing. Lower mean grain yields coupled with higher price discounts (due to FDK and DON above and test weight below thresholds) resulted in wide-row management programs being among the least economically beneficial in 2014 and 2015. In fact, price discounts and yield reduction due to FHB and leaf rust also resulted in most modified programs, regardless of row spacing, being less economically beneficial than the reference program in 2014 and 2015. Although the fungicide treatments helped to counteract the negative effects of FHB and rust, grain yield and quality gains due to the treatments were generally not sufficient to offset $\mathrm{N}$ and fungicide costs.

Agronomic practices are constantly being evaluated to improve the efficiency, productivity, and profitability of crop production systems, and in some cases, farm operations as a whole. This is certainly the case for wheat in Ohio and other parts of the Midwest. Here we present findings that would be invaluable for growers and crop consultants making decisions regarding $\mathrm{N}$ application rates and wide row spacing in wheat without relay intercropping with soybean. Our results suggest that in most years, savings related to machinery and seed cost alone may not be sufficient to offset yield reduction due to wide row spacing (low planting density) and nitrogen cost in wide-row, high-N-rate management programs. Relay intercropping with soybean (a crop that is generally more profitable than wheat) and higher seeding rates may be useful options for making wide-row wheat production systems more economically feasible. However, further research would be needed to better understand how these factors interact to affect yield and profitability under growing conditions in Ohio. But given the observed effects of $\mathrm{N}$ on rust and row spacing on FHB and DON, relay intercropping and seeding rate will likely not reduce price discounts due to poor grain quality and disease-related yield loss. A disease management plan will have to be an integral part of any program that includes high $\mathrm{N}$ rates and wide row spacing. When using higher $\mathrm{N}$ rates, producers will have to be more diligent scouting and treating for leaf rust (and other diseases such as powdery mildew that are known to increase with $\mathrm{N}$ [Olesen et al. 2003]). Moreover, given that higher production cost due to fungicide application may reduce profitability, an option would be to choose a cheap, but effective fungicide (likely one that is off patent). The most economically viable option would be to choose the best leaf rust-resistant cultivars. Cultivar selection will also be extremely important for those interested in planting wide-row wheat, not only from the standpoint of selecting high-tillering cultivars that are adapted to production in wide rows, but also from the standpoint of FHB resistance. And since resistance and fungicide alone are only about $50 \%$ effective against FHB (Paul et al. 2008b), an integrated strategy will have to be used (Willyerd et al. 2012) to minimize grain yield and quality losses due to FHB and associated price discounts.

\section{Acknowledgments}

This investigation is based on work supported by the Ohio Small Grains Marketing Program. Salaries and research support for J. D. Salgado, L. E. Lindsey, and P. A. Paul were provided by state and federal funds to the Ohio Agricultural Research and Development Center. Special thanks to R. Minyo, K. Davies, J. Engle, F. Dalla Lana, J. A. Rios, W. B. Moraes, L. Ault, W. Bardall, R. Barry, and J. Heller for assisting with establishment, maintenance, and harvest of research plots and treatment application.

\section{Literature Cited}

Amarasinghe, C. C., Tamburic-Ilincic, L., Gilbert, J., Brûlé-Babel, A. L., and Dilantha Fernando, W. G. 2013. Evaluation of different fungicides for control of fusarium head blight in wheat inoculated with 3ADON and 15ADON chemotypes of Fusarium graminearum in Canada. Can. J. Plant Pathol. 35:200-208.

Bancal, M.-O., Roche, R., and Bancal, P. 2008. Late foliar diseases in wheat crops decrease nitrogen yield through $\mathrm{N}$ uptake rather than through variations in $\mathrm{N}$ remobilization. Ann. Bot. (Lond.) 102:579-590.

Barker, D., Culman, S., Dorrance, A., Fulton, J., Haden, R., Lentz, E., Lindsey, A., Lindsey, L., Loux, M., McCoy, E., Michel, A., Noel, J., Paul, P., Sulc, M., Thomison, P., Tilmon, K., and Witter, J. 2017. Ohio Agronomy Guide, 15th edition, Bulletin 472. The Ohio State University.

Bhathal, J. S., Loughman, R., and Speijers, J. 2003. Yield reduction in wheat in relation to leaf disease from Yellow (tan) spot and Septoria nodorum blotch Eur. J. Plant Pathol. 109:435-443.

Broscious, S. C., Frank, J. A., and Frederick, J. R. 1985. Influence of winter wheat management practices on the severity of powdery mildew and septoria blotch in Pennsylvania. Phytopathology 75:538-542.

Champion, G. T., Froud-Williams, R. J., and Holland, J. M. 1998. Interactions between wheat (Triticum aestivum L.) cultivar, row spacing and density and the effect on weed suppression and crop yield. Ann. Appl. Biol. 133:443-453.

Danial, D. L., and Parlevliet, J. E. 1995. Effects of nitrogen fertilization on disease severity and infection type of yellow rust on wheat genotypes varying in quantitative resistance. J. Phytopathol. 143:679-681.

Denys, C. J., O'Halloran, I. P., and Lauzon, J. D. 2006. Effect of nitrogen fertilization and topography on soft red winter wheat yield and protein content in two Ontario landscapes. Can. J. Soil Sci. 86:729-739.

Devadas, R., Simpfendorfer, S., Backhouse, D., and Lamb, D. W. 2014. Effect of stripe rust on the yield response of wheat to nitrogen. Crop J. 2:201-206.

Dimmock, J. P. R. E., and Gooding, M. J. 2002. The effects of fungicides on rate and duration of grain filling in winter wheat in relation to maintenance of flag leaf green area. J. Agric. Sci. 138:1-16.

Dordas, C. 2008. Role of nutrients in controlling plant diseases in sustainable agriculture. A review. Agron. Sustain. Dev. 28:33-46.

Fauzi, M. T., and Paulitz, T. C. 1994. The effect of plant growth regulators and nitrogen on Fusarium head blight of the spring wheat cultivar Max. Plant Dis. 78:289-292.

Frederick, J. R., and Bauer, P. J. 1999. Physiological and numerical components of wheat yield. Pages 45-65 in: Wheat: Ecology and Physiology of Yield Determination. E. H. Satorre and G. A. Slafer, eds. Food Products Press, Binghamton, NY.

Gandorfer, M., and Rajsic, P. 2008. Modeling economic optimum nitrogen rates for winter wheat when inputs affect yield and output-price. Agric. Econ. Res. 9:54-64.

Gaunt, R. E. 1995. The relationship between plant disease severity and yield. Annu. Rev. Phytopathol. 33:119-144.

Gooding, M. J. 2007. Influence of foliar diseases and their control by fungicides on grain yield and quality in wheat. Pages 557-565 in: Wheat Production in Stressed Environments. H. T. Buck, J. E. Nisi, and N. Salomón, eds. Springer, The Netherlands.

Gooding, M. J., Dimmock, J. P. R. E., France, J., and Jones, S. A. 2000. Green leaf area decline of wheat flag leaves: the influence of fungicides and relationships with mean grain weight and grain yield. Ann. Appl. Biol. 136:77-84. 
Heier, T., Jain, S. K., Kogel, K. H., and Pons-Kuehnemann, J. 2005. Influence of $\mathrm{N}$-fertilization and fungicide strategies on Fusarium head blight severity and mycotoxin content in winter wheat. J. Phytopathol. 153:551-557.

Howard, D. D., Chambers, A. Y., and Logan, J. 1994. Nitrogen and fungicide effects on yield components and disease severity in wheat. J. Prod. Agric. 7:448-454.

Huber, D. M., and Watson, R. D. 1974. Nitrogen form and plant disease. Annu. Rev. Phytopathol. 12:139-165.

Hussain, M., Farooq, S., Jabran, K., Ijaz, M., Sattar, A., and Hassan, W. 2016. Wheat sown with narrow spacing results in higher yield and water use efficiency under deficit supplemental irrigation at the vegetative and reproductive Stage. Agronomy (Basel) 6:22.

Hussain, M., Mehmood, Z., Khan, M. B., Farooq, S., Lee, D. J., and Farooq, M. 2012. Narrow row spacing ensures higher productivity of low tillering wheat cultivars. Int. J. Agric. Biol. 14:413-418.

Kolb, L. N., Gallandt, E. R., and Mallory, E. B. 2012. Impact of spring wheat planting density, row spacing, and mechanical weed control on yield, grain protein, and economic return in Maine. Weed Sci. 60:244-253.

Lackermann, K. V., Conley, S. P., Gaska, J. M., Martinka, M. J., and Esker, P. D. 2011. Effect of location, cultivar, and diseases on grain yield of soft red winter wheat in Wisconsin. Plant Dis. 95:1401-1406.

Lafond, G. P. 1994. Effects of row spacing, seeding rate and nitrogen on yield of barley and wheat under zero-till management. Can. J. Plant Sci. 74:703-711.

Large, E. C. 1954. Growth stage in cereals, illustrations of the Feekes' scale. Plant Pathol. 3:128-129.

Lee, C. D., and Herbek, J. H. 2012. Winter wheat yield response to wide rows varies by year in the southern Ohio River Valley. Crop Manage. doi:10.1094/ CM-2012-1030-01-RS

Leitch, M. H., and Jenkins, P. D. 1995. Influence of nitrogen on the development of Septoria epidemics in winter wheat. J. Agric. Sci. 124:361-368.

Lemmens, M., Haim, K., Lew, H., and Ruckenbauer, P. 2004. The effect of nitrogen fertilization on Fusarium head blight development and deoxynivalenol contamination in wheat. J. Phytopathol. 152:1-8.

Littell, R. C., Milliken, G. A., Stroup, W. W., Wolfinger, R. D., and Schabenberger, O. 2006. SAS for Mixed Models, 2nd Ed. SAS Institute, Cary, NC.

Liu, X., Jiang, J., Shao, J., Yin, Y., and Ma, Z. 2010. Gene transcription profiling of Fusarium graminearum treated with an azole fungicide tebuconazole. Appl. Microbiol. Biotechnol. 85:1105-1114.

Lupton, F. G. H. 1972. Further experiments on photosynthesis and translocation in wheat. Ann. Appl. Biol. 71:69-79.

Mali, H., and Choudhary, J. 2012. Performance of bread wheat (Triticum aestivum L.) varieties under different row spacing. J. Wheat Res. 4:55-57.

May, W. E., Fernandez, M. R., Selles, F., and Lafond, G. P. 2014. Agronomic practices to reduce leaf spotting and Fusarium kernel infections in durum wheat on the Canadian prairies. Can. J. Plant Sci. 94:141-152.

McMullen, M., Bergstrom, G., De Wolf, E., Dill-Macky, R., Hershman, D., Shaner, G., and Van Sanford, D. 2012. A unified effort to fight an enemy of wheat and barley: Fusarium head blight. Plant Dis. 96:1712-1728.

Murray, G., Wellings, C., Simpfendorfer, S., and Cole, C. 2005. Stripe rust: Understanding the disease in wheat. Fact sheet NSW. Department of Primary Industries, Australia. https://www.dpi.nsw.gov.au/_data/assets/pdf_file/0006/158964/ stripe-rust-in-wheat.pdf

Neumann, S., Paveley, N. D., Beed, F. D., and Sylvester-Bradley, R. 2004. Nitrogen per unit leaf area affects the upper asymptote of Puccinia striiformis f.sp. tritici epidemics in winter wheat. Plant Pathol. 53:725-732.

Nutter, F. W., Jr., and Litwiller, D. 1998. A computer program to generate standard area diagrams to aid raters in assessing disease severity. Phytopathology 88:S117.

Oldenburg, E., Bramm, A., and Valenta, H. 2007. Influence of nitrogen fertilization on deoxynivalenol contamination of winter wheat: Experimental field trials and evaluation of analytical methods. Mycotoxin Res. 23:7-12.

Olesen, J. E., Jorgensen, L. N., Petersen, J., and Mortensen, J. V. 2003. Effects of rates and timing of nitrogen fertilizer on disease control by fungicides in winter wheat. 2. Crop growth and disease development. J. Agric. Sci. 140:15-29.

Orth, C. E., and Grybauskas, A. P. 1994. Development of Septoria nodorum blotch on winter wheat under two cultivation schemes in Maryland. Plant Dis. 78:736-741.

Parker, J. E., Warrilow, A. G. S., Cools, H. J., Martel, C. M., Nes, W. D., Fraaije, B. A., Lucas, J. A., Kelly, D. E., and Kelly, S. L. 2011. Mechanism of binding of prothioconazole to Mycosphaerella graminicola CYP51 differs from that of other azole antifungals. Appl. Environ. Microbiol. 77:1460-1465.

Paul, P. A., Beuerlein, J., Loux, M., Lentz, E., Hammond, R., and Mullen, R. 2008a. Improving Wheat Profits in Ohio. Bull. 938. The Ohio State University/OSUE.
Paul, P. A., El-Allaf, S. M., Lipps, P. E., and Madden, L. V. 2005. Relationships between incidence and severity of Fusarium head blight on winter wheat in Ohio. Phytopathology 95:1049-1060.

Paul, P. A., Lipps, P. E., Hershman, D. E., McMullen, M. P., Draper, M. A., and Madden, L. V. 2008b. Efficacy of triazole-based fungicides for Fusarium head blight and deoxynivalenol control in wheat: A multivariate meta-analysis. Phytopathology 98:999-1011.

Porter, P. M., and Khalilian, A. 1995. Wheat response to row spacing in relay intercropping systems. Agron. J. 87:999-1003.

Richer, E., and Lindsey, L. E. 2016. On-farm investigation of seeding rate for wide-row wheat production in northwest Ohio. Crop Forage Turfgrass Manage. doi:10.2134/cftm2015.0204

Robert, C., Bancal, M.-O., and Lannou, C. 2002. Wheat leaf rust uredospore production and carbon and nitrogen export in relation to lesion size and density. Phytopathology 92:762-768.

Robert, C., Bancal, M.-O., and Lannou, C. 2004. Wheat leaf rust uredospore production on adult plants: Influence of leaf nitrogen content and Septoria tritici blotch. Phytopathology 94:712-721.

Robert, C., Bancal, M.-O., Ney, B., and Lannou, C. 2005. Wheat leaf photosynthesis loss due to leaf rust, with respect to lesion development and leaf nitrogen status. New Phytol. 165:227-241.

Ruske, R. E., Gooding, M. J., and Jones, S. A. 2003. The effects of adding picoxystrobin, azoxystrobin and nitrogen to a triazole programme on disease control, flag leaf senescence, yield and grain quality of winter wheat. Crop Prot. 22:975-987.

Salgado, J. D., Madden, L. V., and Paul, P. A. 2014. Efficacy and economics of integrating in-field and harvesting strategies to manage Fusarium head blight of wheat. Plant Dis. 98:1407-1421.

Salgado, J. D., Madden, L. V., and Paul, P. A. 2015. Quantifying the effects of Fusarium head blight on grain yield and test weight in soft red winter wheat. Phytopathology 105:295-306.

Salgado, J. D., Wallhead, M., Madden, L. V., and Paul, P. A. 2011. Grain harvesting strategies to minimize grain quality losses due to Fusarium head blight in wheat. Plant Dis. 95:1448-1457.

Sandler, L., Nelson, K. A., and Dudenhoeffer, C. 2015. Winter wheat row spacing and alternative crop effects on relay-intercrop, double-crop, and wheat yields. Int. J. Agron. 2015:369243

Shaner, G., and Finney, R. E. 1977. The effect of nitrogen fertilization on the expression of slow-mildewing resistance in Knox wheat. Phytopathology 67: 1051-1056.

Simpson, G. M. 1968. Association between grain yield per plant and photosynthetic area above the flag leaf node in wheat. Can. J. Plant Sci. 48:253-260.

Stone, P. J., and Savin, R. 1999. Grain quality and its physiological determinants. Pages 85-120 in: Wheat: ecology and physiology of yield determination. E. H. Satorre and G. A. Slafer, eds. Food Products Press, Birmingham, NY.

Subedi, K. D., Ma, B. L., and Xue, A. G. 2007. Planting date and nitrogen effects on fusarium head blight and leaf spotting diseases in spring wheat. Agron. J. 99:113-121.

Teich, A. H., and Hamilton, J. R. 1985. Effect of cultural practices, soil phosphorus, potassium, and $\mathrm{pH}$ on the incidence of Fusarium head blight and deoxynivalenol levels in wheat. Appl. Environ. Microbiol. 49:1429-1431.

Teich, A. H., Sampson, D. R., Shugar, L., Smid, A., Curnoe, W. E., and Kennema, C. 1987. Yield, quality and disease response of soft white winter wheat cultivars to nitrogen fertilization in Ontario, Canada. Cereal Res. Commun. 15:265-272.

van Ginkel, M., McNab, A., and Krupinsky, J., eds. 1999. Septoria and Stagonospora Diseases of Cereals: A Compilation of Global Research. Proceedings of the Fifth International Septoria Workshop, September 1999, CIMMYT, Mexico.

Willyerd, K. T., Bradley, C. A., Chapara, V., Conley, S. P., Esker, P., Madden, L. V., Wise, K. A., and Paul, P. A. 2015. Revisiting fungicide-based management guidelines for leaf blotch diseases in soft red winter wheat. Plant Dis. 99 1434-1444

Willyerd, K. T., Li, C., Madden, L. V., Bradley, C. A., Bergstrom, G. C., Sweets, L. E., McMullen, M., Ransom, J. K., Grybauskas, A., Osborne, L., Wegulo, S. N., Hershman, D. E., Wise, K., Bockus, W. W., Groth, D., Dill-Macky, R., Milus, E., Esker, P. D., Waxman, K. D., Adee, E. A., Ebelhar, S. E., Young, B. G., and Paul, P. A. 2012. Efficacy and stability of integrating fungicide and cultivar resistance to manage Fusarium head blight and deoxynivalenol in wheat. Plant Dis. 96:957-967.

Yoshida, M., Nakajima, T., and Tonooka, T. 2008. Effect of nitrogen application at anthesis on Fusarium head blight and mycotoxin accumulation in breadmaking wheat in the western part of Japan. J. Gen. Plant Pathol. 74:355-363. 